\title{
Quantitative Inversion of Water-Inrush Incidents in Mountain Tunnel beneath a Karst Pit
}

\author{
Fei Wan, ${ }^{1}$ Peiwen Xu, ${ }^{2}$ Peng Zhang $\mathbb{D},{ }^{2,3}$ Hongfu Qu, ${ }^{4}$ Lihua Wang, ${ }^{4}$ and Xuan Zhang ${ }^{1}$ \\ ${ }^{1}$ Research Institute of Highway, Ministry of Transport, Beijing 100088, China \\ ${ }^{2}$ College of Transportation Science \& Engineering, Nanjing Tech University, Nanjing 210009, China \\ ${ }^{3}$ Institute of Nanjing Intelligent Geotechnical Engineering, Nanjing 210023, China \\ ${ }^{4}$ The Fourth Engineering Co., Ltd., of CCCC First Highway Engineering Co., Ltd., Nanning 530031, China \\ Correspondence should be addressed to Peng Zhang; zhangpeng-mail@163.com
}

Received 17 March 2021; Accepted 14 July 2021; Published 22 July 2021

Academic Editor: Husnain Haider

Copyright (c) 2021 Fei Wan et al. This is an open access article distributed under the Creative Commons Attribution License, which permits unrestricted use, distribution, and reproduction in any medium, provided the original work is properly cited.

\begin{abstract}
Quantitative inversion of accidents is an important work of finding the cause of accidents and avoiding their recurrence. However, quantitative inversion of accidents is difficult due to the lack and limitation of accidents monitoring information. Focusing on water-inrush incidents of Jiguan Mountain tunnel, this paper proposes a set of workflows to find out the missing conditions and quantitative inversion of accidents by flow analysis and structural safety analysis on the basis of investigating the rain capacity and water outflow in water-inrush incidents. First, hydraulic boundary in water-inrush incidents is acquired by analyzing the relationship of catchment, infiltration, and accumulation of rainwater in karst pit using the flooding algorithm of ArcGIS and the topographic mapping of UAV photogrammetry. Second, the permeability coefficients of karst infiltration zone and tunnel surrounding rock are acquired by two-step decoupling and inverse analyzing the water inflow, flow rate, and interval time between rainfall and water inrush. Third, tunnel accidents of the overload of tunnel lining induced by the catchment and infiltration of karst pit under extreme rainfall conditions are numerically simulated by using FLAC. The results indicate that quantitative inversion of water-inrush incidents reveals the process and cause of accidents and provides the safety index of tunnel structure. Not only is the water-inrush incidents of karst tunnel controlled by hydrogeology conditions, but also the rainfall recharge should not be ignored.
\end{abstract}

\section{Introduction}

Karst pit is a typical karst geomorphic unit, the hydrogeological conditions of which are significantly controlled by the recharge from the rainwater catchment of karst pit. In a tunnel pass through beneath a karst pit, when instantaneous rainstorms occur, rainfall-runoff is collected by karst pit and quickly drained through a doline, local groundwater skyrockets in a short time and breaks through the discharge capacity of conventional waterproof and drainage designs. It gives rise to the lining to bear short-term ultrahigh external water pressure in rainy season. In the construction period of Jiguan Mountain tunnel, multiple accidents of water-inrush incidents related to rainfall occurred to cause geological hazards and damage to the newly built tunnel lining.
Geological disasters, such as water inrush, mud inrush, and collapse, are often encountered in the construction process of various underground projects [1-5]. Leaking water can damage tunnel installations and form icicles that may cause danger to traffic or other problems for the tunnels activities $[6,7]$. To divert leaking water in tunnels without lining, conventional drainage is today installed [8]. Conventional drainage consists of foamed polyethylene (PE) mats which are suspended on rock mounted threaded rods. The PE mats are assembled with different steel fittings and placed approximately $5-30 \mathrm{~cm}$ from the rock wall. The entire drainage structure is then covered with conventional reinforced shotcrete for mechanical protection and reduces the polyethylene mats' fire risk. Waterproofing and drainage system plays an important role in the control of external 
water pressure on the lining. The waterproof lining can increase the external water pressure [9], but a drainage system can decrease it [8]. Many researchers investigated how the external water pressure affected the lining's mechanical characteristics by analytical analysis, numerical simulations, and physical tests [10-12]. In the engineering practice, some strategies, including grouting and pin-hole drain method, have been proposed based on these research studies [13-16]. Many studies focus on the waterproofing and drainage system for tunnels, which significantly affects linings' external water pressure. Yuan et al. [17] systematically summarized the waterproofing requirements and measures in different special tunnels in China. Jang et al. [18] measured various types of geocomposites in a laboratory to evaluate their filtration and discharge capacity characteristics for their potential application in tunnels. Yoo [19] presented an investigation into the effect of the decrease in drainage capacity by the hydraulic deterioration of tunnel geosynthetic drainage systems on tunnel linings' structural performance. Other researchers explored the mechanism of seepage-induced water inrush and the mitigation of water inrush [20-26]. All the above studies indicate that the precondition of safety evaluating the drainage system design is an accurate estimation of the external water pressure on lining induced by groundwater.

Quantitative inversion of accidents is an important work of finding the cause of accidents and avoiding their recurrence. However, quantitative inversion of accidents is difficult due to the lack and limitation of accidents monitoring information. Focusing on water-inrush incidents of Jiguan Mountain tunnel, although the rain capacity and water outflow in water-inrush incidents are monitored, the main causes of damaging tunnel structure lining, such as the pressure on tunnel structure, the permeability of surrounding rock, and the hydraulic boundary of rainfall, cannot be directly known. This paper proposes a set of stepby-step workflows to obtain the main causes and quantitative inversion of accidents by flow analysis and fluidstructure interaction analysis on the basis of investigating the rain capacity and water outflow in water-inrush incidents.

\section{Methodologies of Evaluation}

The workflow of quantitative inversion is divided into four steps in the study, as illustrated by the flowchart in Figure 1:

Step 1: the information of site conditions is collected, including topography, meteorology, and hydrology. The DEM of topography in karst pit is surveyed by UAV photogrammetry, and the geological model of karst pit is acquired by electrical geophysical prospecting.

Step 2: the watershed division of karst pit and the relationship of catchment, infiltration, and accumulation of rainwater in karst pit are acquired by hydrologic analysis tool and flooding algorithm of ArcGIS according to the rain capacity, water inflow, and flow rate in water-inrush incidents during construction.
Step 3: the permeability coefficients of karst infiltration zone and tunnel surrounding rock are acquired by twostep decoupling and inverse analyzing the water inflow, flow rate, and interval time between rainfall and water inrush.

Step 4: on the basis of the relationship of catchment, infiltration, and accumulation of rainwater in Step 2 and the permeability coefficients of karst infiltration zone and tunnel surrounding rock in Step 3, the drainage system of tunnel is evaluated by numerically simulating the overload of tunnel lining induced by the catchment and infiltration of karst pit under extreme rainfall conditions using FLAC.

This paper is organized as follows: Section 3 presents site conditions including topography, meteorology, and hydrology; Section 4 presents rainwater catchment and accumulation analysis; Section 5 presents inverse analysis of permeability coefficients; Section 6 presents safety evaluation of drainage system; and Section 7 concludes this study.

\section{Site Conditions}

Jiguan Mountain tunnel is located in Lushan Town, Weining County, Liupanshui City, Guizhou Province, China, as shown in Figure 2 and is built for crossing the watershed between Lexi and Qinggou stretched from northeast to southwest, which is an extra-long separated tunnel where the left line is $3772 \mathrm{~m}$ long and the maximum burial depth is about $178 \mathrm{~m}$, and the right line is $3800 \mathrm{~m}$ long and the maximum burial depth is about $150 \mathrm{~m}$. The tunnel passes through a karst pit in the range between $\mathrm{ZK} 72+220$ and $\mathrm{ZK} 72+340$, the roof of which is $79 \mathrm{~m}$ below the bottom of the karst pit as shown in Figure 3.

The geological features of Jiguan Mountain tunnel belong to the karst tectonic of peak cluster and the uvula landform. A series of karst pit, uvula, and karst funnels are distributed along the boundary between Qixia Formation and Liangshan Formation in pure limestone. A karst pit overlying Jiguan Mountain tunnel has a diameter of $120 \mathrm{~m}$, a depth of $50 \mathrm{~m}$, and the shape of an irregular circle. There is a doline located at the bottom of karst pit with a depth of more than $15 \mathrm{~m}$ by visual inspection. Photos of the karst pit and doline are shown in Figure 4.

The setting of Jiguan Mountain tunnel is located in the subtropical monsoon zone with abundant rainfall. According to the meteorological data of Weining County, rainfall is mainly concentrated from May to October, the annual average rainfall is $960.6 \mathrm{~mm}$, and the maximum daily rainfall is $166 \mathrm{~mm}$. In rainy season, sheet flows are gathered along the grooves of slope surface and imported into karst funnels, uvula, and karst pit to recharge groundwater.

\section{Rainwater Catchment and Accumulation Analysis}

4.1. UAV Photogrammetry to DEM. UAV photogrammetry system is used to obtain $3 \mathrm{D}$ point cloud data for constructing the DEM data describing the terrain of karst pit. UAV 


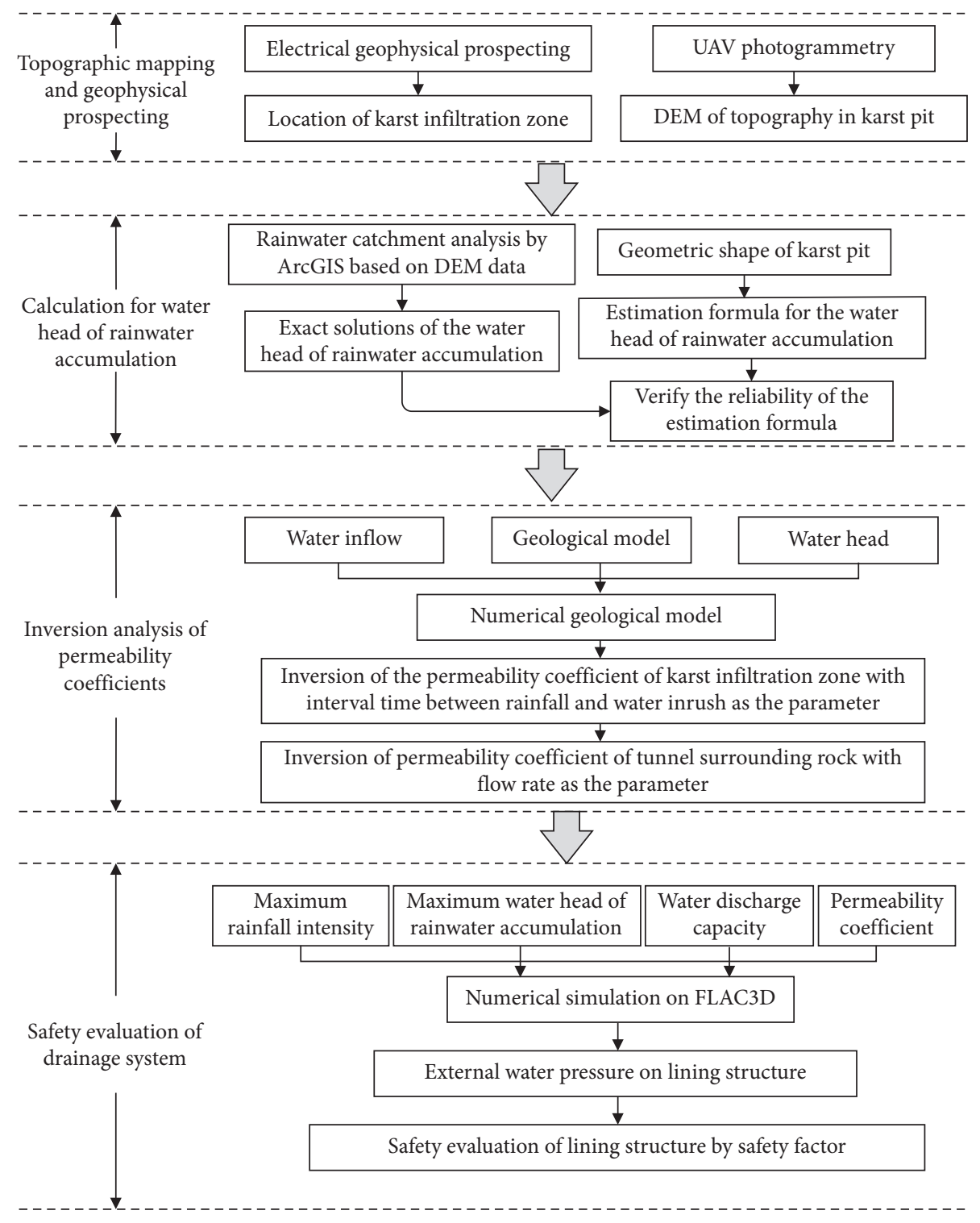

FIgURE 1: Flowchart of the quantitative inversion.

system includes the four-axis aerial UAV of DJI M210 and the camera of DJI ZENMUSE X5S. The surveying area is about $1.577 \mathrm{~km}^{2}$, a rectangle with $1200 \mathrm{~m}$ from north to south and $1300 \mathrm{~m}$ from east to west. The workflow of UAV photogrammetry consists of eight steps: (1) determining the survey area, (2) UAV assembly and inspection, (3) flight route planning, (4) flight parameters setting, (5) flight mode planning, (6) aerial survey flight, (7) grounding marking of control points, and (8) GPS mapping of control points, as shown in Figure 5(a). UAV photogrammetry acquires a total of 338 orthographic images, some of which are shown in Figure 5(b). Pix4Dmapper software is used to solve 3D point cloud data, DOM, and DSM describing the terrain of karst pit from 338 orthographic images and GPS coordinates of controlling points by aerotriangulation, dense point clouds, constructing TIN data, and texture mapping. DOM data have a specific color difference due to weather conditions. $3 \mathrm{D}$ point cloud data is imported into ArcGIS and transformed into DEM data with the resolution of $0.5 \mathrm{~m}$ using the tool of LAS point Statistics as Raster tool according to the sampling mode of PULSE_COUNT. DOM data, DSM data, point cloud data, and DEM data are shown in Figure 5(c).

4.2. Rainwater Catchment Analysis by ArcGIS. To calculate the rainwater catchment of karst pit, the first important work is to acquire the watershed of karst pit. Hydrologic analysis tool on ArcGIS is used to analyze the DEM data of the surveying area, including five steps: (1) flow analysis, (2) flux analysis, (3) flow distance analysis, (4) confluence analysis, and (5) watershed segmentation on preferred flooding algorithm. As a result, the value of flow direction is, respectively, $1,2,4,8,16,32,64$, and 128, which represents the eight directions of east, southeast, south, southwest, west, northwest, north, and northeast, 


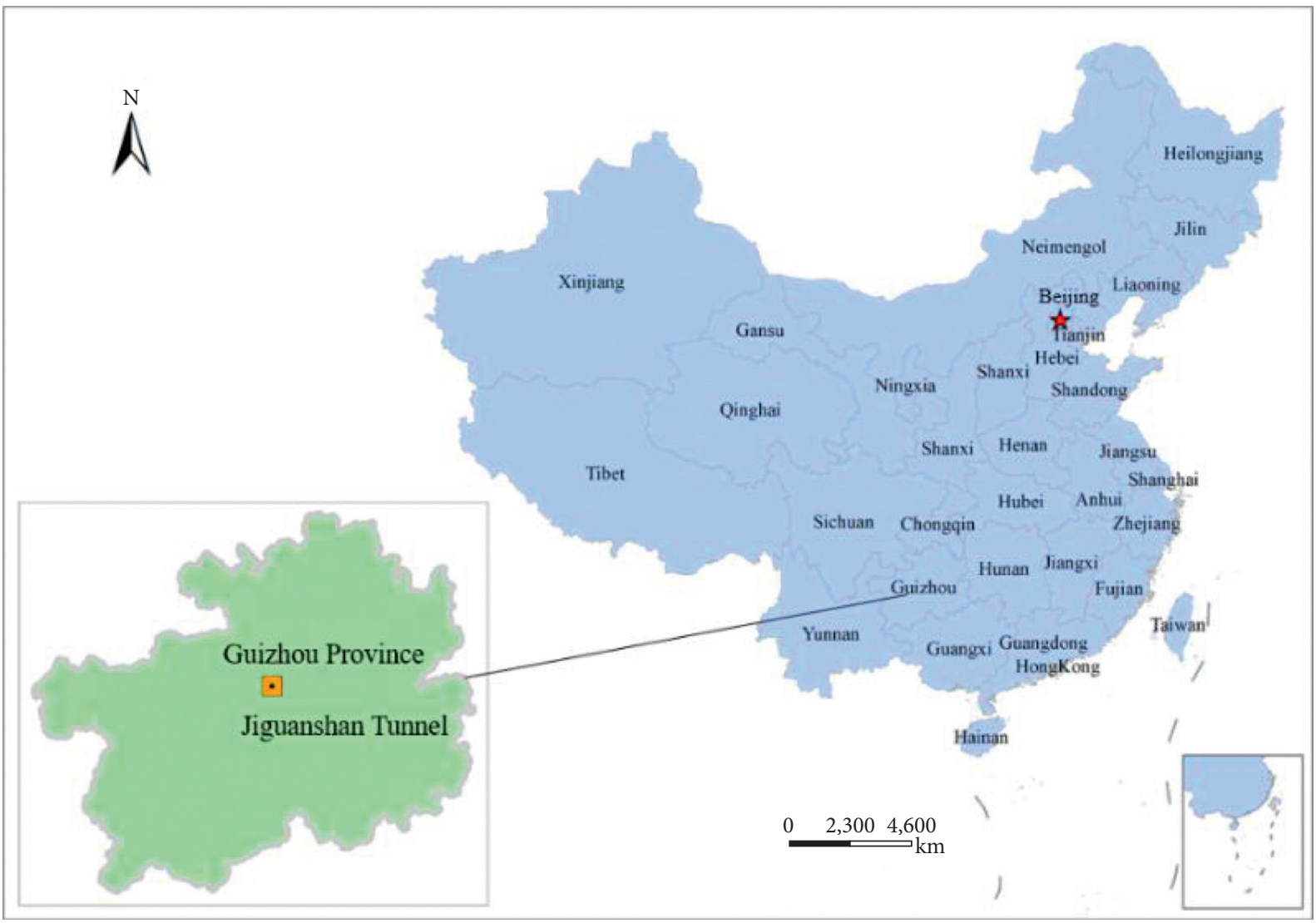

Figure 2: Location of Jiguan Mountain tunnel.

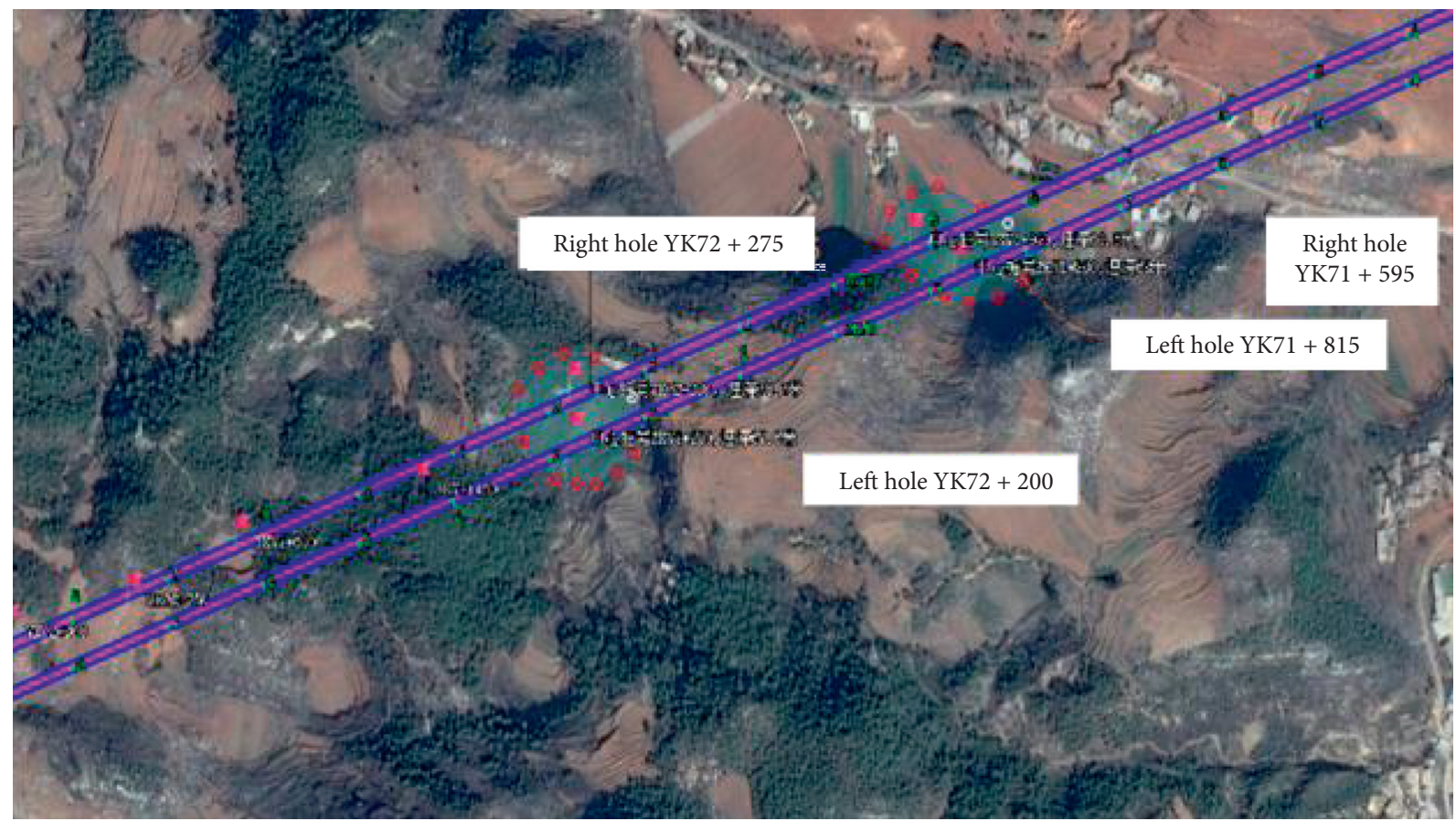

FIgURE 3: The route of the Jiguan Mountain tunnel.

respectively, as shown in Figure 6(a). The confluence flow is calculated based on the value of the water flowing at each point in the flow direction data, as shown in Figure 6(b).
The catchment threshold is determined to be 100. After trial and error, the confluence river networks are calculated, as shown in Figure 6(c). The watershed segmentation is 


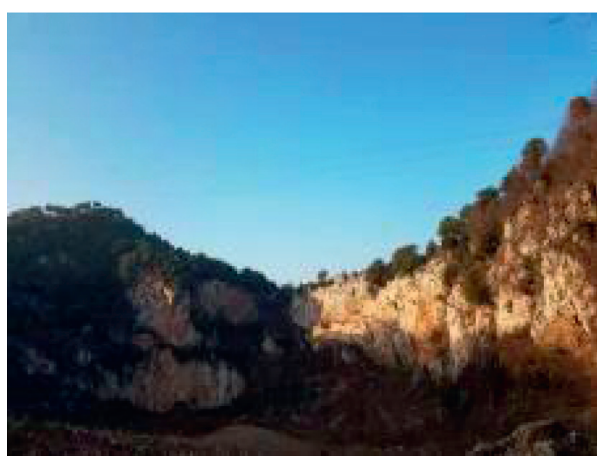

(a)

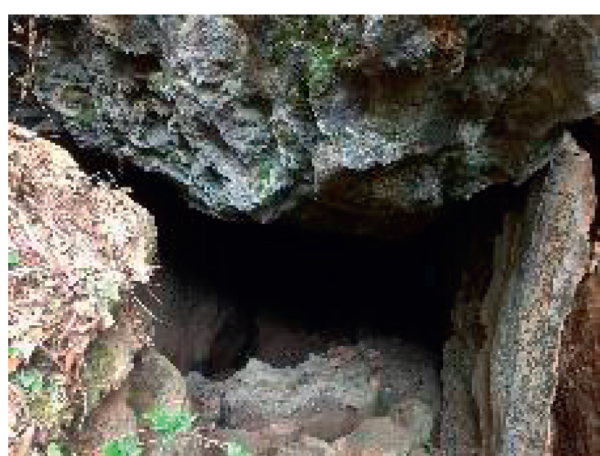

(b)

Figure 4: Karst pit and doline.

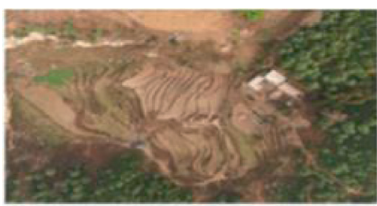

Selected survey area
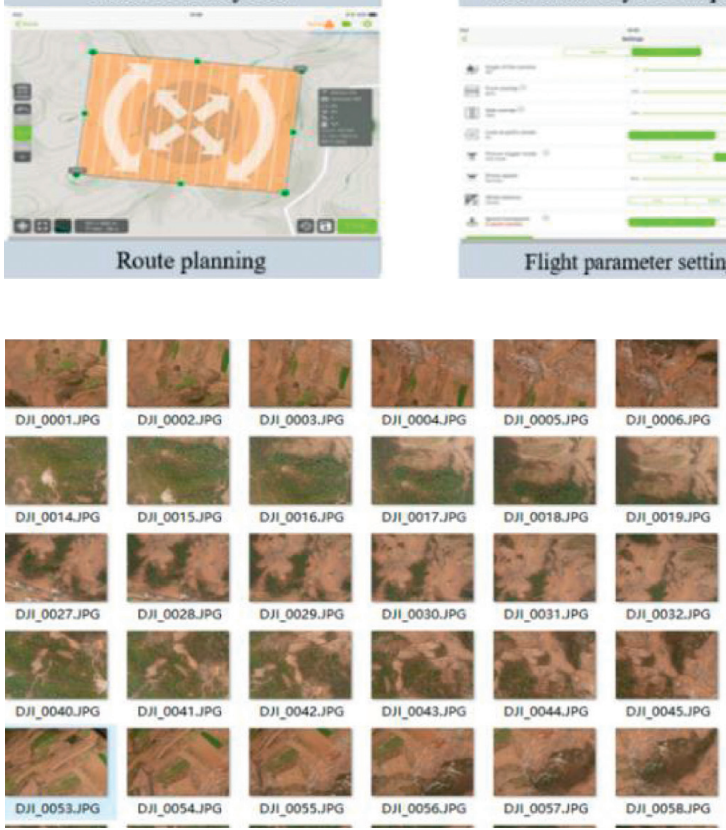

DII_0058APG
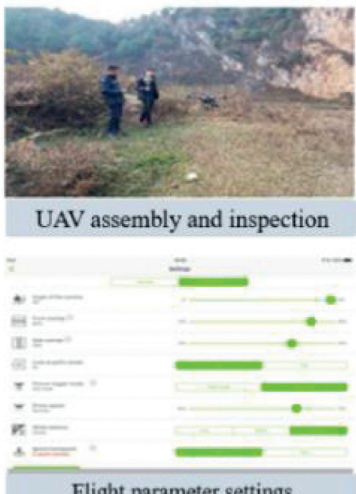

(a)
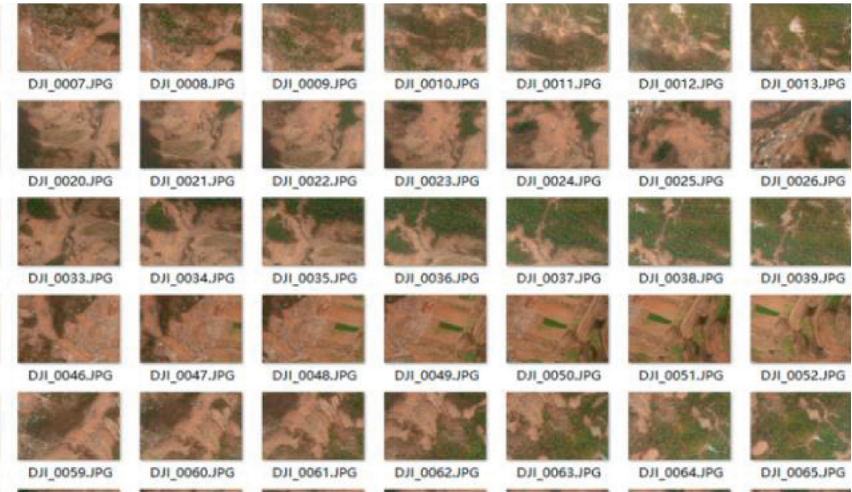

(b)
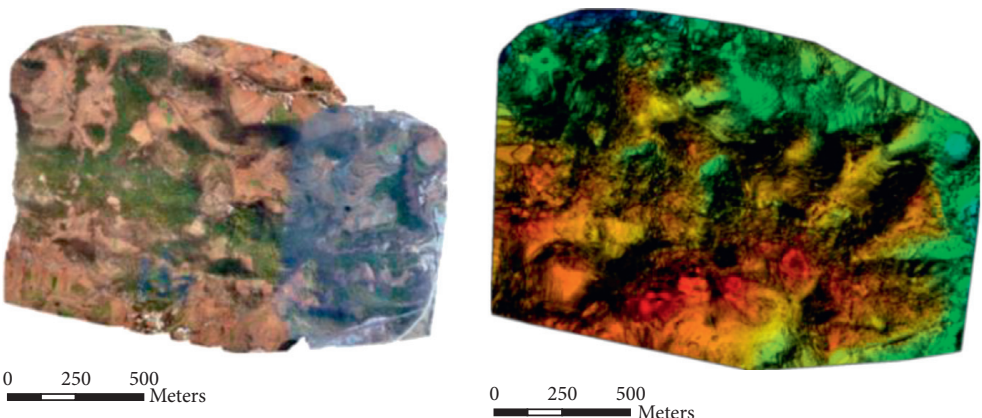

(c)

FIGURE 5: Digital terrain results: (a) workflow of UAV photogrammetry; (b) partial orthographic images; (c) DOM, DSM, and DEM data. 

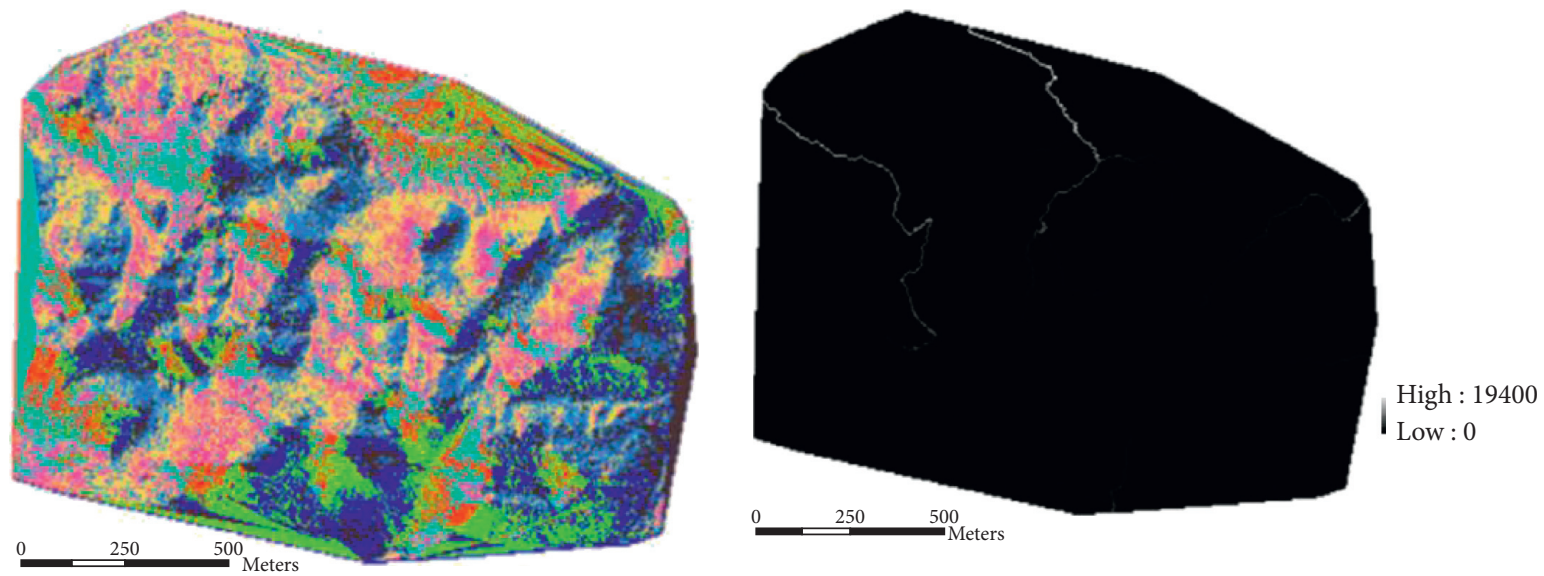

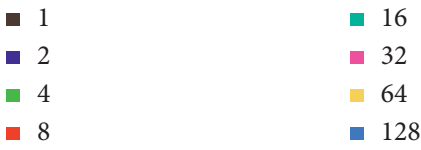

(a)

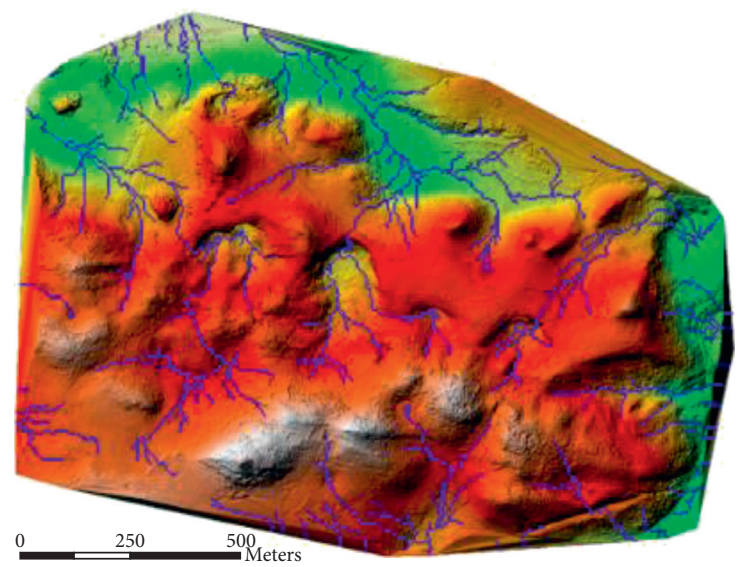

(c)

16

128 (b)

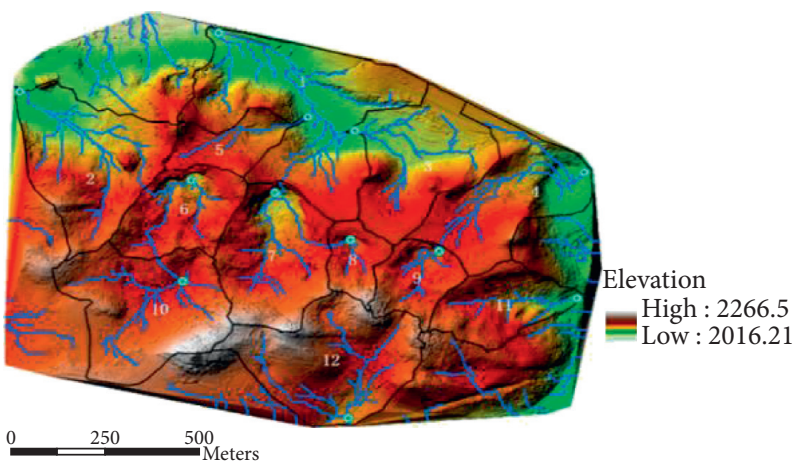

- Outlet

Watersbed

Confluence

network

(d)

FIGURE 6: Catchment analysis and watershed division: (a) value of flow direction; (b) confluence flow; (c) confluence river networks; (d) watershed segmentation.

divided using the hydrological tools of ArcGIS, as shown in Figure 6(d). It is divided into 12 watersheds' segmentation ( 5 of which are inflow areas and 7 of which are outflow areas). The largest watershed area is $0.1919 \mathrm{~km}^{2}$, and the smallest one is $0.0307 \mathrm{~km}^{2}$. The watershed attributes are shown in Table 1.

4.3. Rainwater Accumulation Analysis by ArcGIS. Water-inrush incidents in tunneling construction are closely related to intensive rainfall. When the discharge flow rate of doline at the bottom of karst pit is less than rainfall intensity, it begins rainwater accumulation at the bottom of karst pit. Rainwater accumulation of a karst pit is determined by the runoff of catchment and the discharge flow of doline at the bottom of karst pit. One part of the discharge flow pours into the drainage system of tunnel during tunnel operation or causes the water inrush during tunneling construction, and the other part of the discharge flow goes into the groundwater system. Due to the fact that the part of the discharge flow going into the groundwater system is inestimable, it can be supposed to be a specific water-inrush ratio in the tunnel. So the discharged flow QI can be expressed as

$$
Q_{I}=(1+\eta) \cdot Q_{g}
$$

where $\eta$ is the coefficient of flowing into the groundwater system and $Q_{g}$ is the yield of water inrush. Given Jiguan Mountain tunnel beneath a karst pit, $\eta$ is regarded as the minimum value under extreme rainfall conditions. In other projects, the value range of $\eta$ is $0.2 \sim 0.5$ according to the relative position between tunnel and karst pit. 
TABLE 1: Watershed attributes.

\begin{tabular}{lcc}
\hline Number & Type & Area $\left(\mathrm{km}^{2}\right)$ \\
\hline 1 & Outflow & 0.1919 \\
2 & Outflow & 0.1338 \\
3 & Outflow & 0.1132 \\
4 & Outflow & 0.1127 \\
5 & Outflow & 0.0407 \\
6 & Inflow & 0.0720 \\
7 & Inflow & 0.1085 \\
8 & Inflow & 0.0307 \\
9 & Inflow & 0.0445 \\
10 & Inflow & 0.1380 \\
11 & Outflow & 0.0640 \\
12 & Outflow & 0.1388 \\
\hline
\end{tabular}

Rainwater accumulation of karst pit can be roughly obtained by the rainfall capacity minus the discharge flow, as shown in the following equation:

$$
Q_{a}=\sum_{i}\left(w_{i} t_{i}\right) \cdot S-\sum_{i}\left(Q_{I} \cdot t_{i}\right)
$$

where $Q_{a}$ is the amount of rainwater accumulation, $w$ is the rainfall intensity, $t$ is the duration of rainfall, $S$ is the area of catchment, and $Q_{I}$ is the rate of discharge flow.

The karst pit overlying Jiguan Mountain tunnel is the No. 7 watershed catchment in Table 2, with a total area of $108492 \mathrm{~m}^{2}$. According to the measured water inflow in three water-inrush incidents, the rainwater accumulation of each water-inrush incident is calculated using equation (1) as shown in Table 3.

The height of rainwater accumulation at karst pit is calculated by the flooding algorithm of ArcGIS. The iterative calculation process is shown in Figure 7 and Table 2. The initial height of rainwater accumulation is set to $2110 \mathrm{~m}$ due to the fact that the lowest altitude of the karst pit is $2108 \mathrm{~m}$. The amplitude of water head is set to $1 \mathrm{~m}$ in the first iteration and $0.1 \mathrm{~m}$ in the second iteration. The results of the iterative calculation on the flooding algorithm are shown in Table 4. Under the rainfall condition of $166 \mathrm{~mm}$, it iterates the highly accurate solutions of the rainwater accumulation in other inner basins by formula (3). The calculation results are shown in Table 5.

$$
Q_{g}=2.74 \cdot \alpha \cdot W \cdot S
$$

where $Q_{g}$ is the daily water inflow; $\alpha$ is the rainfall infiltration coefficient, $\alpha=0.7$ (annual) or $\alpha=0.5$ (daily); $W$ is the rainfall capacity; and $S$ is the catchment area $\left(\mathrm{km}^{2}\right)$.

4.4. Rainwater Accumulation on Estimation Method. The geometric shape of karst pit can be generalized into two geometric models as cone and truncated cone, as shown in Figure 8 . The cone or truncated cone's height is based on the difference between the lowest elevation on the erosion peak and the elevation on the bottom around a karst pit. The top diameter of cone or truncated cone is based on the approximate diameter of a karst pit at the lowest elevation of erosion peak. The bottom diameter of truncated cone is based on the approximate diameter of karst pit at its bottom. The above dimensions can be easily obtained from the corresponding topographic map of karst pit.

According to the geometric shape of karst pit, the two types of geometric model as cone and truncated cone are discussed, respectively.

4.4.1. Cone Shape. Based on the cone-shaped volume calculation formula, the water depth $h$ can be expressed as

$$
h=\sqrt[3]{\frac{3 Q(\tan \theta)^{2}}{\pi}},
$$

where $Q$ is the actual amount of rainwater accumulation $\left(\mathrm{m}^{3}\right) ; \theta$ is the slope of karst pit, $\tan \theta=H / R$, and $H$ is the model height of karst pit with cone shape $(\mathrm{m})$, which is the radius on the top of karst pit with cone shape.

4.4.2. Truncated Cone Shape. The relationship between the karst pit with truncated cone shape and the rainwater accumulation volume is that

$$
Q=\frac{1}{2} \pi h\left[r^{2}+\left(r+\frac{h}{\tan \theta}\right)^{2}\right],
$$

where $r$ is the radius on the bottom of karst pit with the truncated cone shape $(\mathrm{m}) ; \tan \theta=H /(R-r)$; and $R$ is the radius on the top of karst pit with truncated cone shape.

Formula (5) can be organized to get a cubic equation of one variable as $h$; formula (6) can use Sheng-jin formula to solve a unary cubic equation, which can obtain the depth of rainwater accumulation.

$$
\frac{\pi}{2(\tan \theta)^{2}} \cdot h^{3}+\frac{r}{\tan \theta} \cdot h^{2}+\frac{1}{2} \pi r^{2} h-Q=0 .
$$

The estimation method can be verified based on the water-inrush incidents. The geometric dimension of karst pit model overlaying tunnel is shown in Table 6. These geometric dimensions are put into the formulas for calculating the height of rainwater accumulation, and the results are compared with the accurate solution based on flooding algorithm of ArcGIS. The calculation results are shown in Table 7 . The results show that the truncated cone's estimated results are $0.2 \mathrm{~m}, 0.0 \mathrm{~m}$, and $0.2 \mathrm{~m}$ away from the ArcGIS iterative inversion results. When the ground in the area of karst pit overlaying tunnel is relatively flat, the prediction result of the truncated generalization model is close to the exact solution based on flooding algorithm of ArcGIS.

Under the rainfall condition of $166 \mathrm{~mm}$, the height of rainwater accumulation is estimated and compared by three methods as shown in Tables 8 and 9. When the bottom of karst pit is steep, the topography of No. 6 and No. 8 basins is similar to the cone shape. When the bottom of karst pit is relatively flat, the topography of the No. 7, No. 9, and No. 10 basins is more similar to the truncated cone shape. It is evident that the generalized conical model results are more accurate when the bottom of karst pit is steep; when the 
TABLE 2: Iterative calculation process.

\begin{tabular}{|c|c|c|c|c|}
\hline $\begin{array}{l}\text { Simulated water level } \\
\text { elevation }(\mathrm{m})\end{array}$ & $\begin{array}{l}\text { Rainwater accumulation area } \\
\qquad\left(\mathrm{m}^{3}\right)\end{array}$ & $\begin{array}{l}\text { Rainwater accumulation } \\
\left(\mathrm{m}^{3}\right)\end{array}$ & $\begin{array}{l}\text { Average water depth } \\
(\mathrm{m})\end{array}$ & $\begin{array}{l}\text { Maximum water depth } \\
(\mathrm{m})\end{array}$ \\
\hline \multicolumn{5}{|l|}{ First iteration } \\
\hline 2110 & 191.25 & 27.61 & 0.14 & 2.04 \\
\hline 2111 & 2137.5 & 1380.55 & 0.65 & 3.04 \\
\hline 2112 & 3251 & 4096.625 & 1.26 & 4.04 \\
\hline 2113 & 3821.5 & 7645.645 & 2 & 5.04 \\
\hline 2114 & 4428 & 11739.26 & 2.65 & 6.04 \\
\hline 2115 & 5223 & 16559.26 & 3.17 & 7.04 \\
\hline 2116 & 5784.5 & 22056.47 & 3.81 & 8.04 \\
\hline 2117 & 6431.25 & 28152.3975 & 4.38 & 9.04 \\
\hline 2118 & 7005.5 & 34899.7375 & 4.98 & 10.04 \\
\hline \multicolumn{5}{|l|}{ Second iteration } \\
\hline 2112.1 & 3321.75 & 4425.3975 & 1.33 & 4.14 \\
\hline 2112.2 & 3389.75 & 4760.235 & 1.4 & 4.24 \\
\hline 2112.3 & 3451.25 & 5102.6275 & 1.48 & 4.34 \\
\hline 2112.4 & 3502.25 & 5449.715 & 1.56 & 4.44 \\
\hline 2112.5 & 3551.5 & 5802.8 & 1.63 & 4.54 \\
\hline 2112.6 & 3604.5 & 6160.8125 & 1.71 & 4.64 \\
\hline 2112.7 & 3660.5 & 6523.44 & 1.78 & 4.74 \\
\hline 2112.8 & 3712.25 & 6892.595 & 1.85 & 4.84 \\
\hline \multicolumn{5}{|l|}{ Third iteration } \\
\hline 2115.1 & 5291.25 & 17085.4975 & 3.23 & 7.14 \\
\hline 2115.2 & 5349.5 & 17616.7475 & 3.29 & 7.24 \\
\hline 2115.3 & 5393.5 & 18154.3825 & 3.37 & 7.34 \\
\hline 2115.4 & 5441.25 & 18695.2325 & 3.44 & 7.44 \\
\hline
\end{tabular}

TABLE 3: Rainwater accumulation of each water-inrush incident.

\begin{tabular}{lcccccc}
\hline Water-inrush incidents & Time & $\begin{array}{c}\text { Rainfall } \\
(\mathrm{mm})\end{array}$ & $\begin{array}{c}\text { Main pit area } \\
\left(\mathrm{m}^{2}\right)\end{array}$ & $\begin{array}{c}\text { Rainwater accumulation } \\
\left(\mathrm{m}^{3}\right)\end{array}$ & $\begin{array}{c}\text { Water inflow } \\
\left(\mathrm{m}^{3}\right)\end{array}$ & $\begin{array}{c}\text { Actual rainwater } \\
\text { accumulation }\left(\mathrm{m}^{3}\right)\end{array}$ \\
\hline 1 & June 4, 2018 & 57.7 & 108492 & 6260.0 & 2134.4 & 4125.6 \\
2 & June 20, 2018 & 82.7 & & 8972.3 & 2641.2 & 6331.1 \\
3 & July 6, 2018 & 234 & & 25387.1 & 7428.9 & 17958.2 \\
\hline
\end{tabular}

bottom of karst pit is relatively flat, the height of rainwater accumulation of the truncated conical generalized model is closer to that predicted by flooding algorithm of ArcGIS.

\section{Inversion Analysis of Permeability Coefficients}

5.1. Electrical Geophysical Prospecting. The high-density electrical geophysical prospecting is used to detect the distribution of karst carve and karst infiltration zone in the tunnel surrounding rock, which adopted a four-pole electrode arrangement for 2-dimensional measurement. Three measuring lines with a length of $1.2 \mathrm{~km}$ were arranged for crossing the karst pit and following the tunnel path. The three measuring lines have 120 electrodes with $360 \mathrm{~V}$ voltage and spacing of 5 meters and their probing depth is about 70 meters. The results of probing and interpreting are shown in Figure 9, which indicates that there are two large faults with SE22 ${ }^{\circ}$ inclination angle of $52^{\circ}$ and $\mathrm{SE} 23^{\circ}$ inclination angle of $59^{\circ}$ which are simplified to construct a numerical geological model as shown in Figure 10.

5.2. Two-step Decoupling. The controlling factors of rainwater infiltration mainly include the permeability coefficients of karst infiltration zone and tunnel surrounding rock, except the boundary of rainwater accumulation in Section 4 . The rainwater infiltration path and time between rainfall time and starting time of water inrush are mainly controlled by the permeability coefficient of karst infiltration zone. The rainwater infiltration amount and rate are mainly controlled by the combined effect of the permeability coefficients of karst infiltration zone and tunnel surrounding rock. Therefore, the ideas of two-step decoupling can be carried out as follows: (1) the interval time between the occurrence of rainfall and the occurrence of starting water inrush is used as a judgment scale to initially determine the permeability coefficient of karst infiltration zone; (2) the flow rate of water inrush inside the tunnel is used as a judgment scale to determine the relative value of the permeability coefficients of karst infiltration zone and tunnel surrounding rock. Decoupling indexes of three water-inrush incidents are listed in Table 10.

5.3. Inversion Analysis. In inversion analysis, the difference in the flow rate of water inrush in the left line of tunnel between numerical analysis and water-inrush incidents is constructed as the objective function, and the step-by-step scanning method is used to iteratively find 

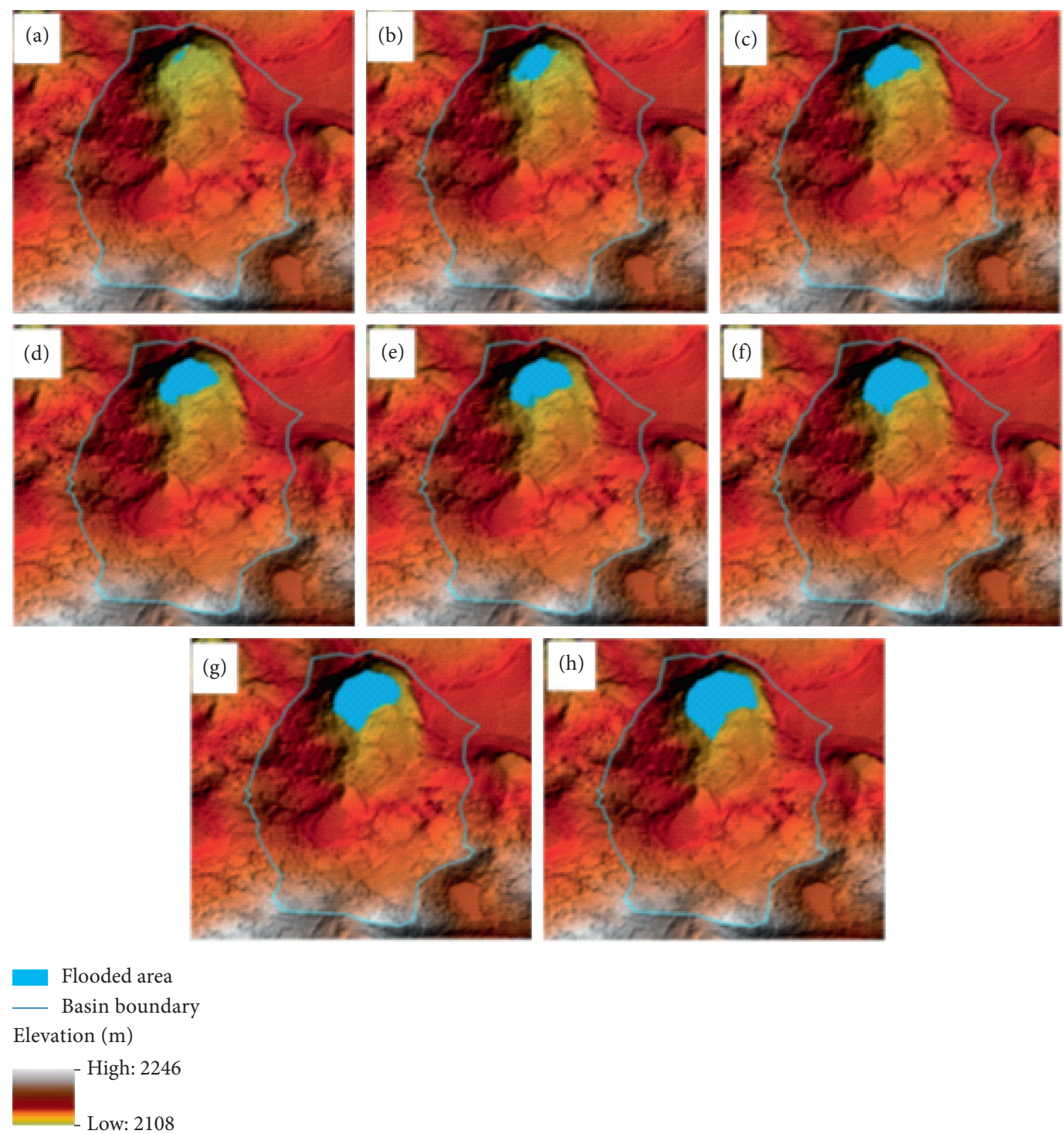

FIgURE 7: Simulation of the iterative calculation process.

TABLE 4: Results of the iterative calculation on the flooding algorithm.

\begin{tabular}{lccc}
\hline Water-inrush incidents & 1 & 2 & 3 \\
\hline Maximum height of rainwater accumulation $(\mathrm{m})$ & 4.0 & 4.6 & 7.3 \\
\hline
\end{tabular}

TABLE 5: Highly accurate solutions of the rainwater accumulation in other inner basins.

\begin{tabular}{|c|c|c|c|c|c|}
\hline Basin number & 6 & 7 & 8 & 9 & 10 \\
\hline Area $\left(\mathrm{km}^{2}\right)$ & 0.07 & 0.11 & 0.03 & 0.04 & 0.14 \\
\hline Maximum daily accumulated water $Q\left(\mathrm{~m}^{3} / \mathrm{d}\right)$ & 11952 & 18009 & 5096 & 7387 & 22908 \\
\hline Maximum infiltration volume based on the maximum daily rainfall $Q\left(\mathrm{~m}^{3} / \mathrm{d}\right)$ & 5973 & 9005 & 2551 & 3690 & 11458 \\
\hline Actual rainwater accumulation $Q\left(\mathrm{~m}^{3} / \mathrm{d}\right)$ & 5979 & 9004 & 2545 & 3697 & 11450 \\
\hline Maximum water depth $(\mathrm{m})$ & 6.90 & 5.30 & 7.10 & 2.00 & 6.80 \\
\hline Basin number & 6 & 7 & 8 & 9 & 10 \\
\hline
\end{tabular}

the minimum value of the objective function for determining the target value of permeability coefficient. The independent variables of the objective function are the permeability coefficient $k_{1}$ of karst infiltration zone and the permeability coefficient $k_{2}$ of tunnel surrounding rock. 


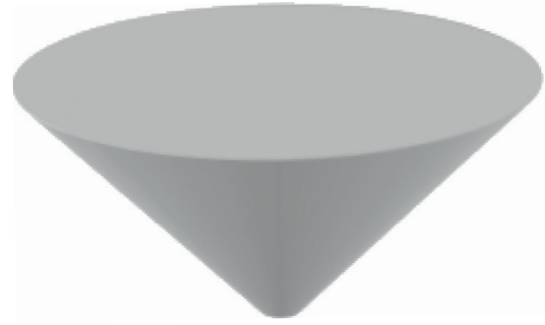

(a)

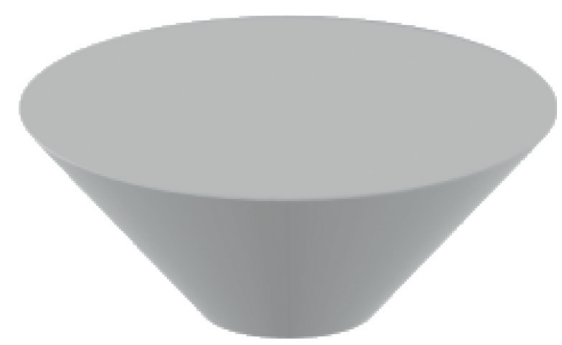

(b)

Figure 8: Geometric models: (a) cone; (b) truncated cone.

TABle 6: Geometric dimension of karst pit model.

\begin{tabular}{lc}
\hline & Main pit \\
\hline Top radius of cone $R(\mathrm{~m})$ & 186.0 \\
Top radius of truncated cone $R(\mathrm{~m})$ & 186.0 \\
Bottom radius of truncated pit $r(\mathrm{~m})$ & 15.0 \\
Height of pit $H(\mathrm{~m})$ & 37.0 \\
Cone $\tan \theta$ & 0.20 \\
Truncated $\operatorname{cone} \tan \theta$ & 0.21 \\
\hline
\end{tabular}

TABLE 7: Calculation results based on water-inrush incidents.

\begin{tabular}{lccc}
\hline Water-inrush incidents & 1 & 2 & 3 \\
\hline ArcGIS iterative inversion results $h(\mathrm{~m})$ & 4.0 & 4.6 & 7.3 \\
Conical geometric model $h(\mathrm{~m})$ & 5.4 & 5.7 & 8.1 \\
Truncated geometric model $h(\mathrm{~m})$ & 3.8 & 4.6 & 7.1 \\
\hline
\end{tabular}

$$
\begin{aligned}
& f\left(k_{1}\right)=\min \sum_{t=1}^{N}\left|x_{t}-X_{t}\right|, \\
& f\left(k_{2}\right)=\min \sum_{t=1}^{N}\left|y_{t}-Y_{t}\right|,
\end{aligned}
$$

where $N$ is the total number of samples; $x_{t}$ is the infiltration time of numerical analysis in the No. $t$ water-inrush incident; $X_{t}$ is the starting time of water inrush in the No. $t$ actual water-inrush incident; $y_{t}$ is the flow rate of water inrush in numerical analysis in the No. $t$ water-inrush incident; and $Y_{t}$ is the flow rate per unit length of water inrush in the No. $t$ actual water-inrush incident.

Unsteady flow analysis on FLAC3D is carried out to numerically simulate the process that rainwater infiltrates into the tunnel through a doline at the bottom of karst pit as to cause the water inrush of tunnel in three water-inrush incidents.

5.3.1. Karst Infiltration Zone. Taking the No. 1 water-inrush incident as an example, the baseline value of the permeability coefficient in karst infiltration zone is $1 \times 10^{-3} \mathrm{~cm} / \mathrm{s}$, and the step size of searching is $1 \times 10^{-4} \mathrm{~cm} / \mathrm{s}$. The relationship between $k_{1}$ and $f\left(k_{1}\right)$ and the curve of water pressure at the monitoring point of tunnel are shown in Figure 11(a). The permeability coefficient in karst infiltration zone can be finally determined to be $1.3 \times 10^{-3} \mathrm{~cm} / \mathrm{s}$. In the No. 2 and
No. 3 water-inrush incidents, the relationship between $k_{1}$ and $f\left(k_{1}\right)$ and the curves of water pressure at the monitoring point of tunnel are shown in Figures 11(b) and 11(c). The permeability coefficients in karst infiltration zone are $1.4 \times 10^{-3} \mathrm{~cm} / \mathrm{s}$ and $4.5 \times 10^{-3} \mathrm{~cm} / \mathrm{s}$. Hence, the permeability coefficient of karst infiltration zone is set as $2.4 \times 10^{-3} \mathrm{~cm} / \mathrm{s}$, which is the average permeability coefficient of karst infiltration zone in three water-inrush incidents as shown in Table 11.

5.3.2. Tunnel Surrounding Rock. The baseline value of the permeability coefficient of tunnel surrounding rock is $1.3 \times 10^{-4} \mathrm{~cm} / \mathrm{s}$, and the step size of searching is $0.2 \times 10^{-4} \mathrm{~cm} / \mathrm{s}$. The relationship between $k_{2}$ and $f\left(k_{2}\right)$ and the curve of peak flow rate of water inrush per length at the monitoring point of tunnel are shown in Figure 12. Hence, the permeability coefficient of tunnel surrounding rock is set as $3.2 \times 10^{-4} \mathrm{~cm} / \mathrm{s}$, which is the average permeability coefficient of tunnel surrounding rock in three water-inrush incidents as shown in Table 11.

\section{Safety Evaluation of Drainage System}

6.1. External Water Pressure on Lining Structure. Unsteady flow analysis on FLAC3D is carried out to numerically simulate the process that rainwater infiltrates into the tunnel through a doline at the bottom of karst pit as to cause the external water pressure on lining structures. According to the maximum rainfall intensity of $234 \mathrm{~mm}$ in the No. 3 waterinrush incident, the maximum water head of rainwater accumulation in karst pit is 7.3 meters using flooding algorithm of ArcGIS. The drainage system with a central trench was used at Jiguan Mountain tunnel, the water discharge capacity of which is $1.21 \mathrm{~m}^{3} / \mathrm{h}$ per unit length of tunnel that is indicated as the flow boundary of $0.6 \mathrm{~m}^{3} / \mathrm{h}$ at both sides' foot of lining wall in numerical simulation. The permeability coefficients of karst infiltration zone and tunnel surrounding rock are, respectively, set as $2.4 \times 10^{-3} \mathrm{~cm} / \mathrm{s}$ and $3.2 \times 10^{-4} \mathrm{~cm} / \mathrm{s}$ according to inversion analysis in Section 5. All the above conditions are put into the boundary of numerical simulation. Water pressure at the monitoring point of tunnel lining (left line and right line) is shown in Figures 13(a) and 13(b) which indicates that water pressure achieves the maximum when the curve is smoothly close to the limit along with the infiltration time. The right arch of the left-line tunnel reaches a maximum of about $12 \mathrm{~m}$ of water head, and the left arch of the right-line reaches a 
TABle 8: Calculation results based on geometric models.

\begin{tabular}{|c|c|c|c|c|c|c|c|c|c|c|}
\hline Basin number & & 6 & & 7 & & 8 & & 9 & & 10 \\
\hline Type & Cone & $\begin{array}{l}\text { Truncated } \\
\text { cone }\end{array}$ & Cone & $\begin{array}{l}\text { Truncated } \\
\text { cone }\end{array}$ & Cone & $\begin{array}{l}\text { Truncated } \\
\text { cone }\end{array}$ & Cone & $\begin{array}{l}\text { Truncated } \\
\text { cone }\end{array}$ & Cone & $\begin{array}{l}\text { Truncated } \\
\text { cone }\end{array}$ \\
\hline Top radius of pit, $R(\mathrm{~m})$ & 151.4 & 151.39 & 186.0 & 186.00 & 98.9 & 98.85 & 119.0 & 119.02 & 209.6 & 209.59 \\
\hline Bottom radius of pit, $r(\mathrm{~m})$ & & 2.00 & & 15.0 & & 1.0 & & 50.0 & & 15.0 \\
\hline $\begin{array}{l}\text { Actual rainwater } \\
\text { accumulation, } Q\left(\mathrm{~m}^{3} / \mathrm{d}\right)\end{array}$ & 5979 & 5979 & 9004 & 9004 & 2545 & 2545 & 3697 & 3697 & 11450 & 11450 \\
\hline Height of pit, $H(\mathrm{~m})$ & 35.1 & 35.13 & 37.0 & 37.0 & 21.5 & 21.5 & 25.0 & 25.0 & 21.5 & 21.4 \\
\hline $\tan \theta$ & 0.23 & 0.24 & 0.20 & 0.21 & 0.22 & 0.22 & 0.21 & 0.36 & 0.1 & 0.11 \\
\hline $\begin{array}{l}\text { Depth of rainwater } \\
\text { accumulation, } h(\mathrm{~m})\end{array}$ & 6.7 & 5.8 & 7.0 & 5.3 & 5.9 & 5.2 & 5.4 & 0.9 & 4.8 & 3.9 \\
\hline
\end{tabular}

TABle 9: Comparison of prediction results.

\begin{tabular}{|c|c|c|c|c|c|}
\hline Basin number & 6 & 7 & 8 & 9 & 10 \\
\hline ArcGIS iterative inversion results, $h(\mathrm{~m})$ & 6.9 & 5.3 & 7.1 & 2.0 & 6.8 \\
\hline Conical geometric model, $h(\mathrm{~m})$ & 6.7 & 7.0 & 5.9 & 5.4 & 4.8 \\
\hline Truncated geometric model, $h(\mathrm{~m})$ & 5.8 & 5.3 & 5.2 & 0.9 & 3.9 \\
\hline
\end{tabular}

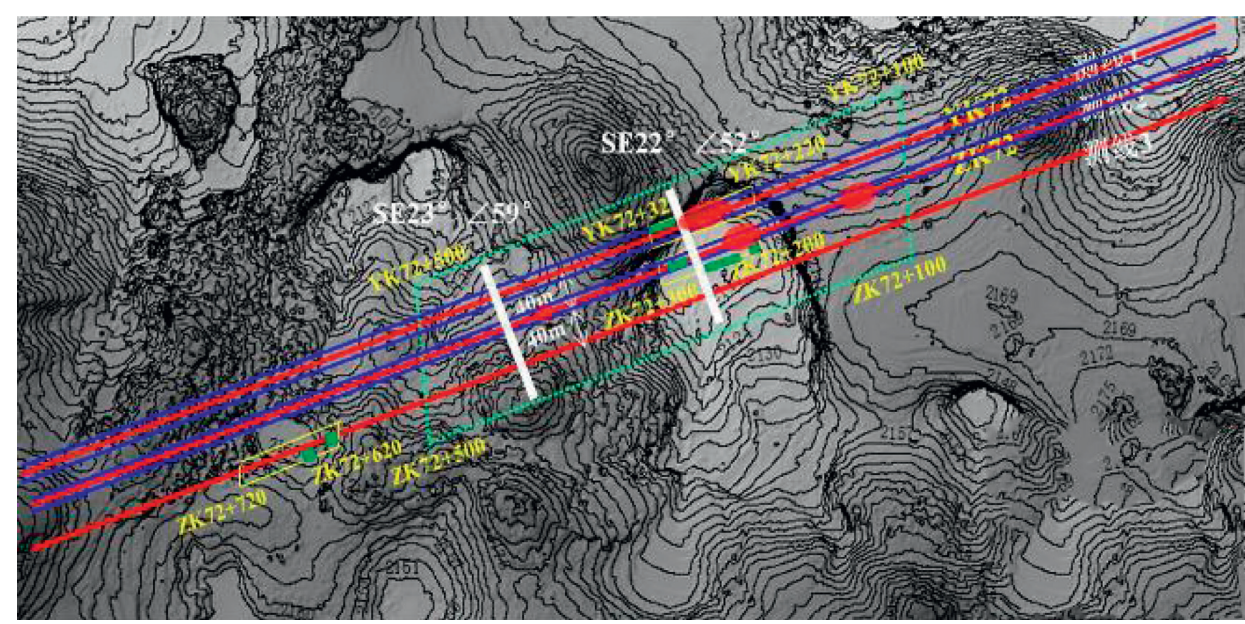

- Tunnel

_ Electrical measurement line

Radar detection area
Study area

- Tunnel leakage zone

- Chamber distribution

(a)

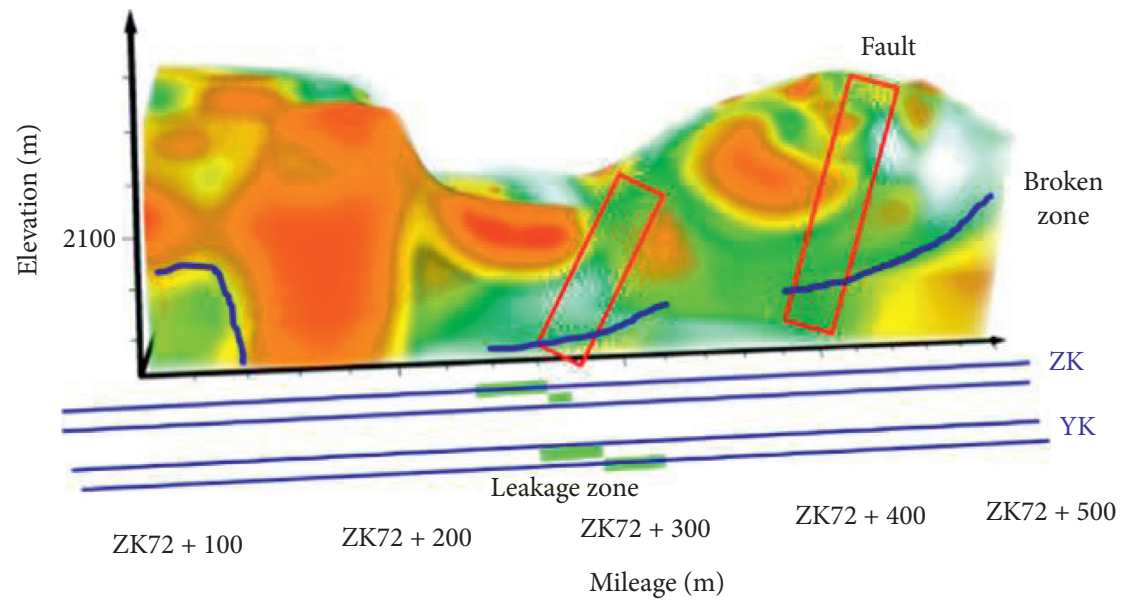

(b)

Figure 9: Continued. 


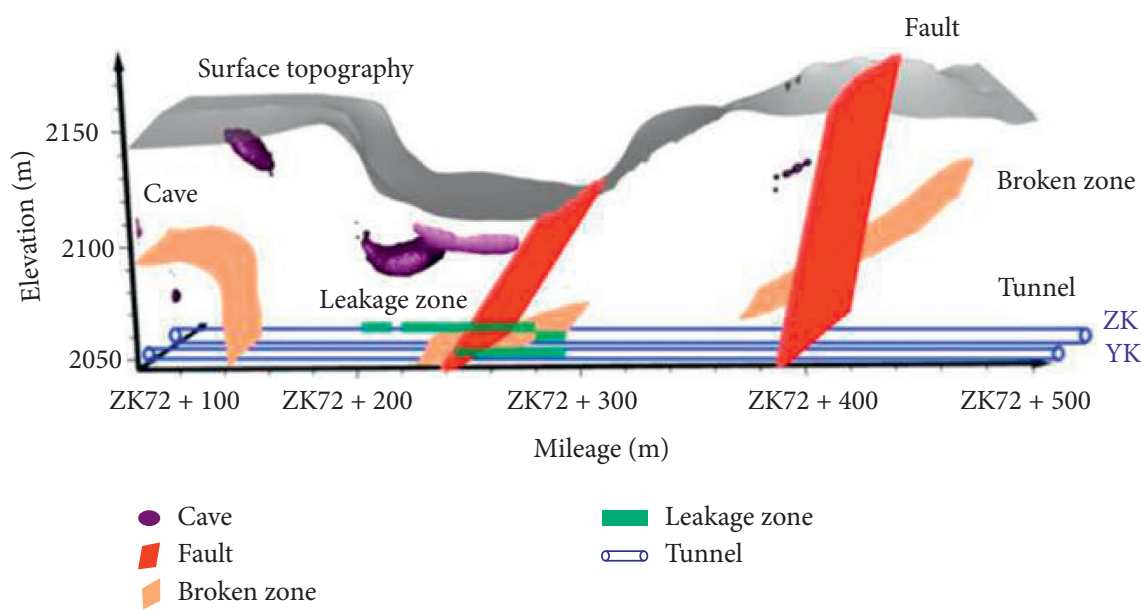

(c)

FIGURE 9: Results of probing and interpreting. (a) Layout map of caverns, fracture zones, and faults; (b) spatial distribution map of caverns, fracture zones, and faults; (c) spatial distribution map of cavities, broken zones, and faults.
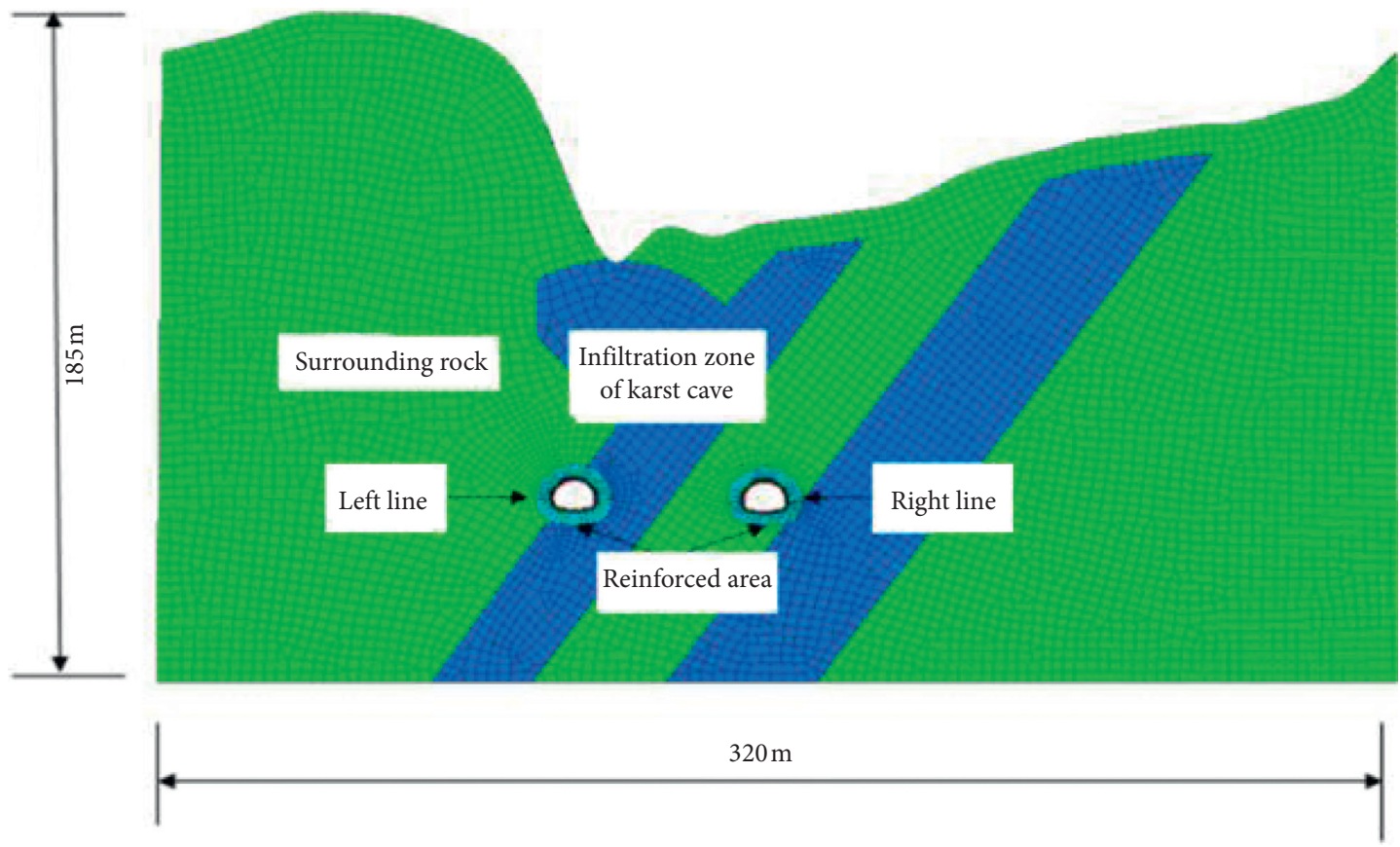

FIGURE 10: Numerical geological model.

TABLe 10: Decoupling indexes of three water-inrush incidents.

\begin{tabular}{|c|c|c|c|c|c|c|c|}
\hline $\begin{array}{l}\text { Water- } \\
\text { inrush } \\
\text { incidents }\end{array}$ & Time & $\begin{array}{l}\text { Rainfall } \\
\text { intensity }\end{array}$ & $\begin{array}{c}\text { Rainfall } \\
(\mathrm{mm})\end{array}$ & $\begin{array}{l}\text { Height of rainwater } \\
\text { accumulation }(\mathrm{m})\end{array}$ & $\begin{array}{l}\text { Time of rainfall } \\
\text { infiltration }(\mathrm{h})\end{array}$ & $\begin{array}{c}\text { Water-inrush } \\
\text { rate } \\
\text { in the left cave } \\
\left(\mathrm{m}^{3} / \mathrm{h}\right)\end{array}$ & $\begin{array}{c}\text { Water-inrush } \\
\text { rate } \\
\text { per length of left } \\
\text { cave }\left(\mathrm{m}^{3} / \mathrm{h}\right)\end{array}$ \\
\hline 1 & June 4, 2018 & Heavy rain for 32 hours & 57.7 & 4.0 & 2 & 584 & 2.6 \\
\hline 2 & June 20, 2018 & Rainstorm for 2 hours & 82.7 & 4.6 & 1 & 1373 & 3.3 \\
\hline 3 & July 6, 2018 & Heavy rain for 3 hours & 234 & 7.3 & 0.5 & 3077 & 6.0 \\
\hline
\end{tabular}




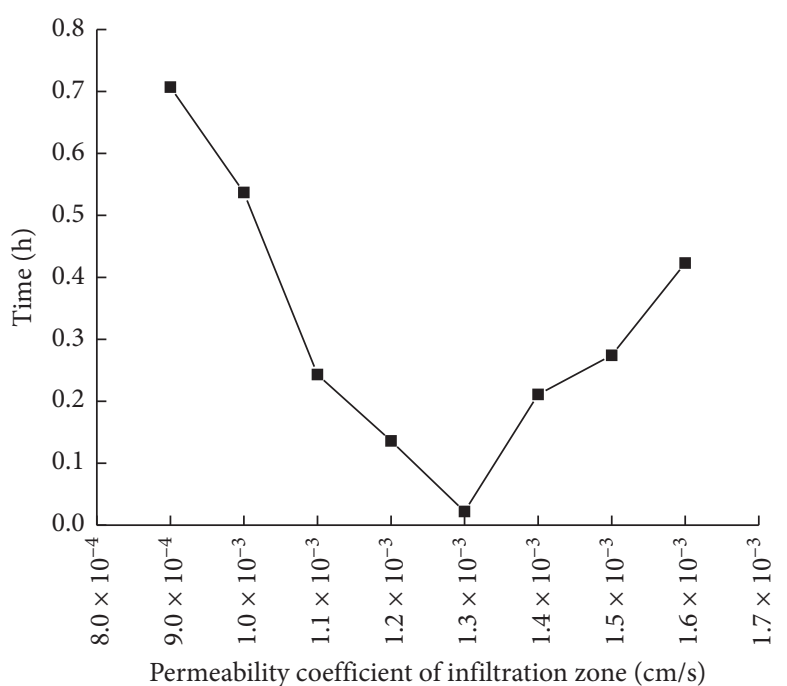

$\rightarrow$ The value of the objective function $f\left(k_{1}\right)$

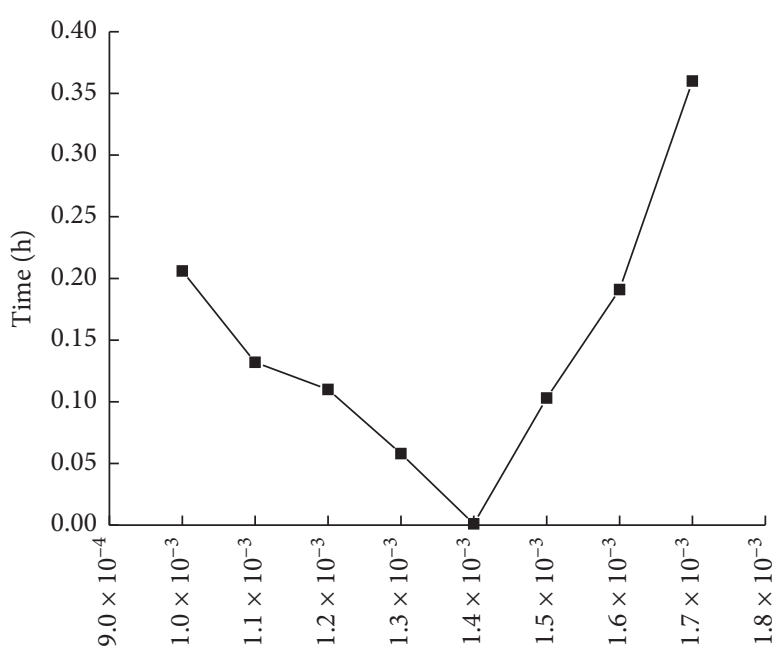

Permeability coefficient of infiltration zone $(\mathrm{cm} / \mathrm{s})$

$\rightarrow$ The value of the objective function $f\left(k_{1}\right)$

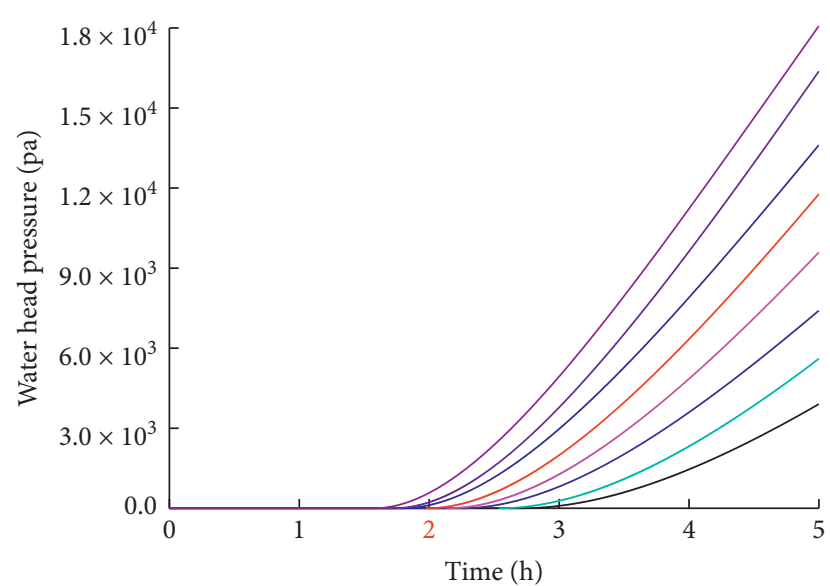

$\begin{array}{ll}-9.0 \times 10^{-4} & -1.3 \times 10^{-3} \\ -1.0 \times 10^{-3} & -1.4 \times 10^{-3} \\ -1.1 \times 10^{-3} & -1.5 \times 10^{-3} \\ -1.2 \times 10^{-3} & -1.6 \times 10^{-3}\end{array}$

(a)

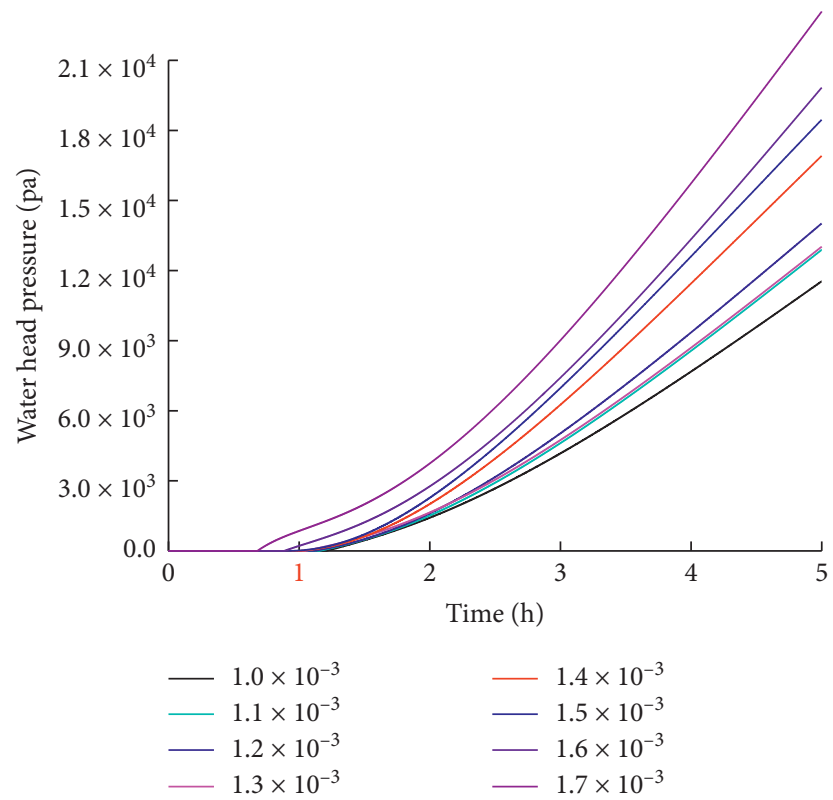

(b)

FIgURE 11: Continued. 


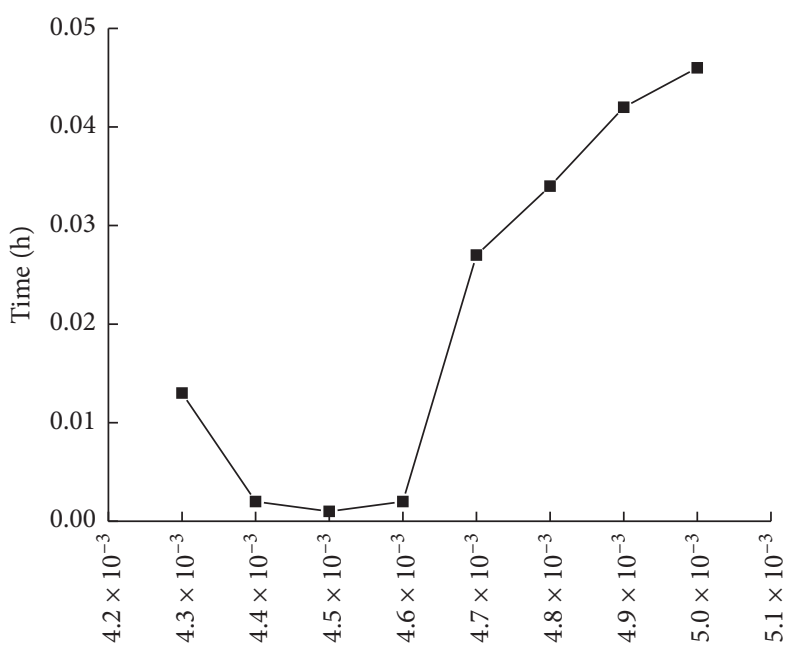

Permeability coefficient of infiltration zone $(\mathrm{cm} / \mathrm{s})$

$\rightarrow$ The value of the objective function $f\left(k_{1}\right)$

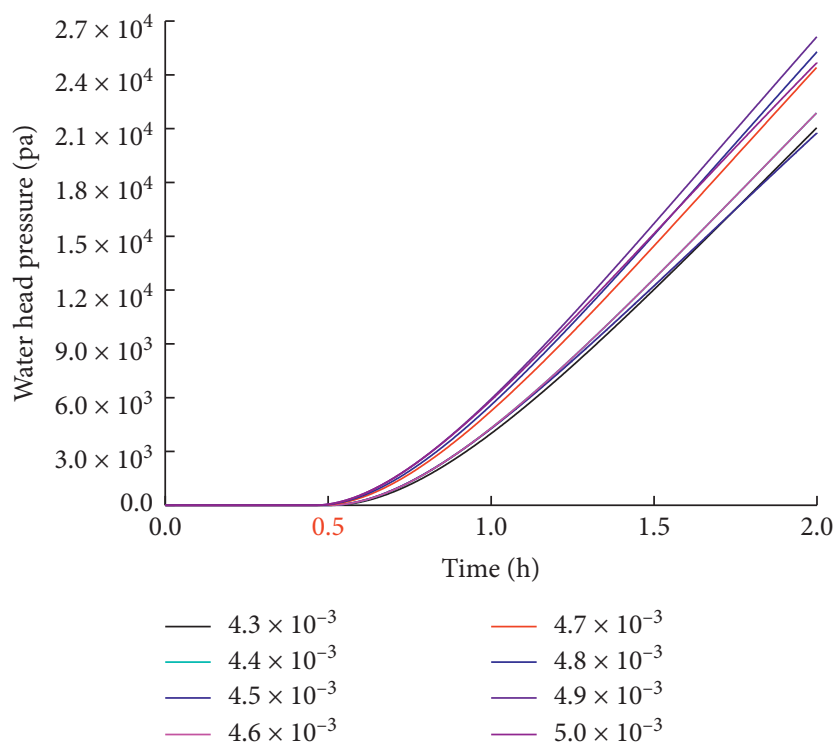

(c)

FIGURE 11: Relationship between objective function and the permeability coefficient of the karst infiltration zone: (a) No. 1 water-inrush incident; (b) No. 2 water-inrush incident; (c) No. 3 water-inrush incident.

TABle 11: Permeability coefficient of inversion analysis.

\begin{tabular}{lcc}
\hline & Karst infiltration zone $(\mathrm{cm} / \mathrm{s})$ & Tunnel surrounding rock $(\mathrm{cm} / \mathrm{s})$ \\
\hline No. 1 water-inrush incident & $1.3 \times 10^{-3}$ & $1.9 \times 10^{-4}$ \\
No. 2 water-inrush incident & $1.4 \times 10^{-3}$ & $2.2 \times 10^{-4}$ \\
No. 3 water-inrush incident & $4.5 \times 10^{-3}$ & $5.5 \times 10^{-4}$ \\
Average & $2.4 \times 10^{-3}$ & $3.2 \times 10^{-4}$ \\
\hline
\end{tabular}

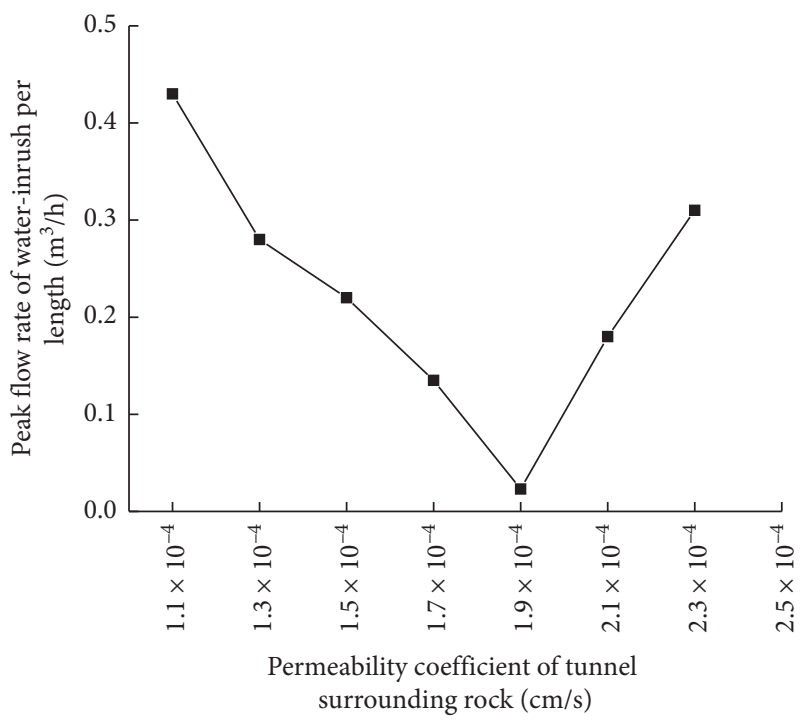

The value of the objective function $f\left(k_{2}\right)$

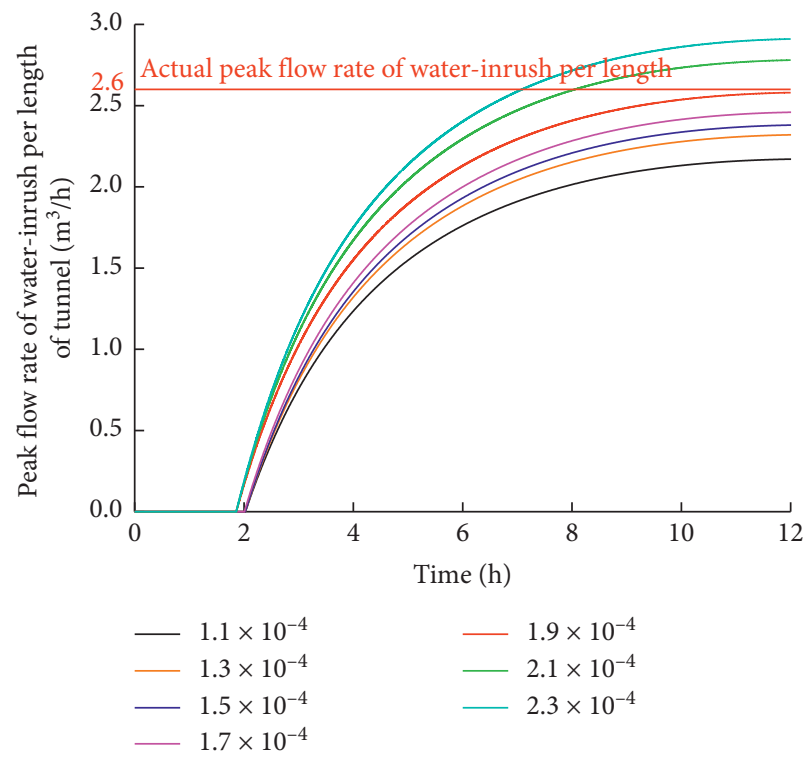

(a)

Figure 12: Continued. 


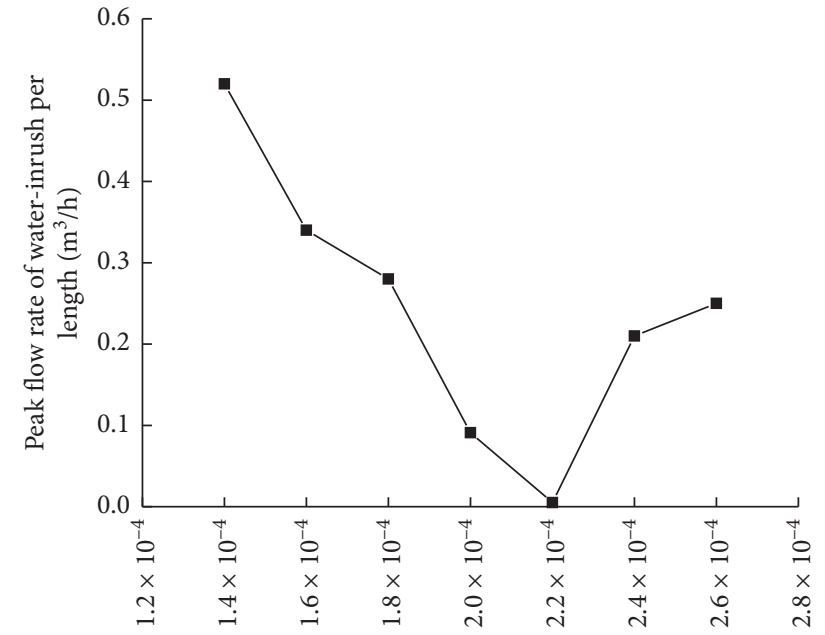

Permeability coefficient of tunnel surrounding rock $(\mathrm{cm} / \mathrm{s})$

The value of the objective function $f\left(k_{2}\right)$

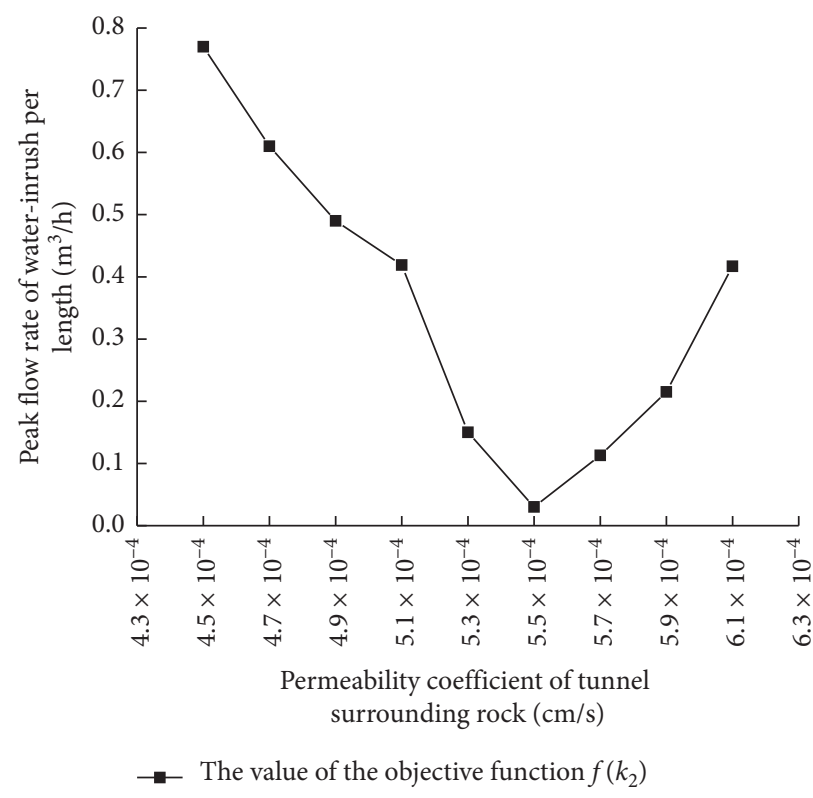

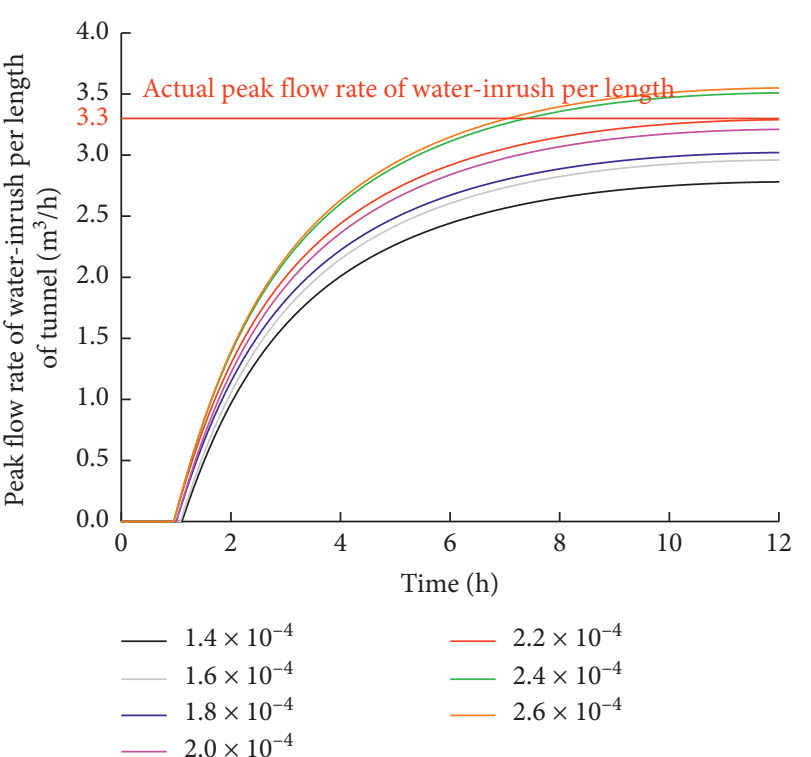

(b)

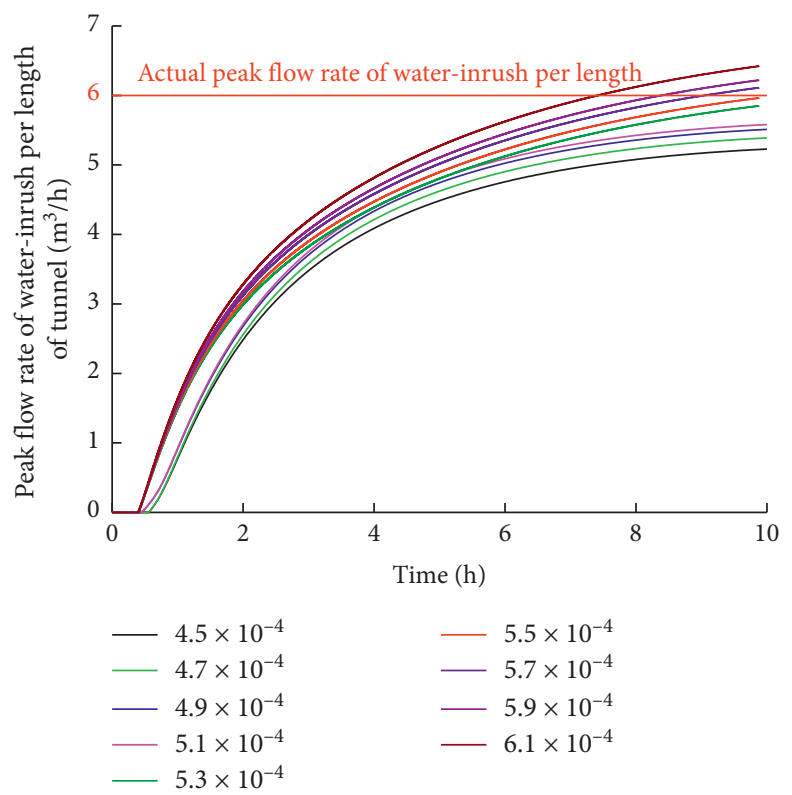

(c)

Figure 12: Relationship between objective function and the permeability coefficient of the tunnel surrounding rock: (a) No. 1 water-inrush incident; (b) No. 2 water-inrush incident; (c) No. 3 water-inrush incident.

maximum of about $8 \mathrm{~m}$ of water head head, and the left arch of the right line of reaches a maximum of about $8 \mathrm{~m}$ of water head.

6.2. Safety Evaluation of Lining Structure. On the basis of acquiring the external water pressure on lining structure, fluid-structure interaction of FLAC is used to numerically simulate the security index of tunnel lining under the external water pressure. In the range between $\mathrm{ZK} 72+220$ and
ZK72 + 340, classification of surrounding rock passing through a karst pit is $\mathrm{V}$ grade. The mechanics parameters of surrounding rock and lining structure are shown in Table 12. Safety evaluation of lining structure mainly relies on the safety factor of the lining's key parts to judge whether the lining reaches the limited water head load it can bear. The safety factors of lining structure are shown in Table 13. When the maximum water head on lining structure is $12 \mathrm{~m}$, 


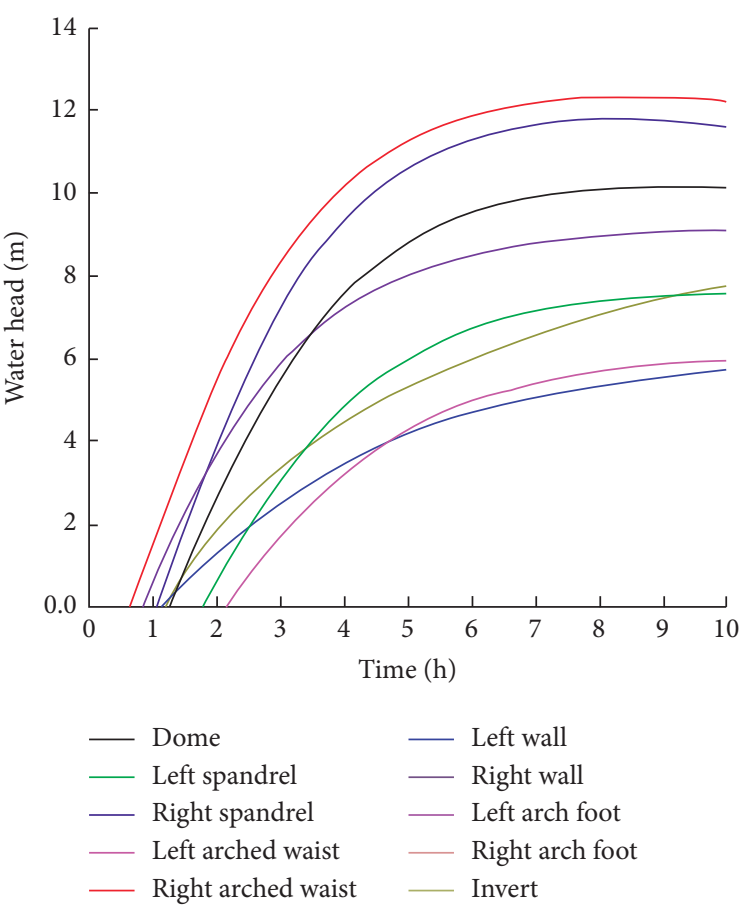

(a)

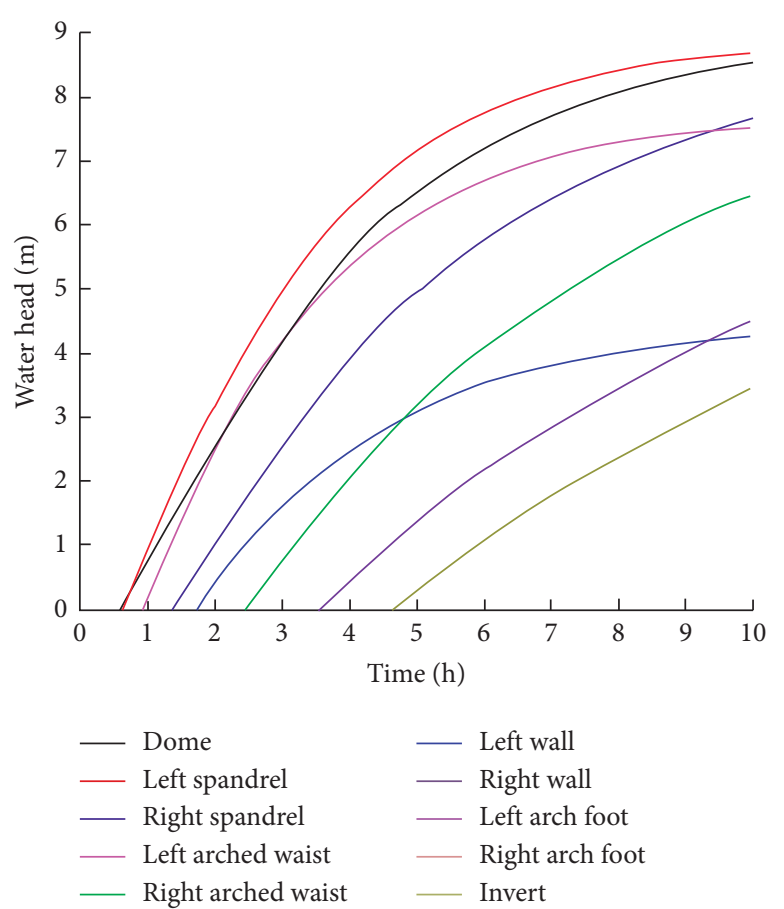

(b)

FIGURE 13: Water pressure at the monitoring point of the tunnel: (a) left line; (b) right line.

TABLE 12: Mechanics parameters of surrounding rock and lining structure.

\begin{tabular}{|c|c|c|c|c|c|c|c|}
\hline $\begin{array}{l}\text { Name of surrounding } \\
\text { rock }\end{array}$ & $\begin{array}{l}\text { Severe } \gamma \\
(\mathrm{kN} / \mathrm{m} 3)\end{array}$ & $\begin{array}{c}\text { Bulk modulus } \\
K(\mathrm{GPa})\end{array}$ & $\begin{array}{l}\text { Shear modulus } \\
\quad G(\mathrm{GPa})\end{array}$ & $\begin{array}{c}\text { Elastic modulus } \\
E(\mathrm{GPa})\end{array}$ & $\begin{array}{l}\text { Poisson's } \\
\text { ratio } \mu\end{array}$ & $\begin{array}{c}\text { Cohesion } C \\
(\mathrm{MPa})\end{array}$ & $\begin{array}{c}\text { Friction } \\
\text { angle } \varphi\left({ }^{\circ}\right)\end{array}$ \\
\hline $\begin{array}{l}\text { Grade V surrounding } \\
\text { rock }\end{array}$ & 18 & 1.67 & 0.56 & 1.5 & 0.35 & 0.1 & 23 \\
\hline Infiltration zone & 16 & 0.83 & 0.18 & 0.5 & 0.4 & 0.05 & 21 \\
\hline $\begin{array}{l}\text { Reinforced Grade V } \\
\text { surrounding rock }\end{array}$ & 19 & 2.8 & 0.9 & 2.5 & 0.35 & 0.2 & 25 \\
\hline $\begin{array}{l}\text { Grade V surrounding of } \\
\text { lining structure }\end{array}$ & 26 & 15.6 & 12.7 & 30 & 0.18 & - & - \\
\hline
\end{tabular}

TABLE 13: Safety factors of lining structure.

\begin{tabular}{|c|c|c|c|c|c|c|c|c|c|c|}
\hline $\begin{array}{l}\text { Key } \\
\text { position }\end{array}$ & Dome & $\begin{array}{c}\text { Left } \\
\text { spandrel }\end{array}$ & $\begin{array}{c}\text { Right } \\
\text { spandrel }\end{array}$ & $\begin{array}{c}\text { Left arched } \\
\text { waist }\end{array}$ & $\begin{array}{c}\text { Right arched } \\
\text { waist }\end{array}$ & $\begin{array}{l}\text { Left } \\
\text { wall }\end{array}$ & $\begin{array}{l}\text { Right } \\
\text { wall }\end{array}$ & $\begin{array}{l}\text { Left arch } \\
\text { foot }\end{array}$ & $\begin{array}{l}\text { Right arch } \\
\text { foot }\end{array}$ & Invert \\
\hline Left line & 1.6 & 1.2 & 0.8 & 1.8 & 0.9 & 1.8 & 1.5 & 2.7 & 1.7 & 1.5 \\
\hline Right line & 2.5 & 2.5 & 5.7 & 1.9 & 5 & 1.8 & 3.2 & 1.8 & 2.9 & 2.8 \\
\hline
\end{tabular}

the safety factor of right spandrel and right arch waist in the left line of the tunnel is less than 1.0, which indicates that the lining has been damaged.

\section{Conclusions}

Based on investigating the rain capacity and water outflow in water-inrush incidents, a synthesized approach of quantitative inversion is proposed to evaluate the safety of tunnel structure on the basis of finding out the key conditions of water-inrush incidents, such as the pressure on tunnel structure, the permeability of surrounding rock, and the hydraulic boundary of rainfall. The pressure on tunnel structure is $12 \mathrm{~m}$ water head, the permeability coefficient of tunnel surrounding rock is set as $3.2 \times 10^{-4} \mathrm{~cm} / \mathrm{s}$, the permeability coefficient of karst infiltration zone is set as $2.4 \times 10^{-3} \mathrm{~cm} / \mathrm{s}$, and the hydraulic boundary of rainfall is $4.6 \mathrm{~m}$ water head. The safety factor of right spandrel and right arch waist in the left line of the tunnel is less than 1.0, where the corresponding position is also the failure location of tunnel structure.

Quantitative inversion of accidents is an important work of finding the cause of accidents and avoiding their recurrence. This paper proposes a set of step-by-step workflows to obtain the main causes and quantitative inversion of accidents by flow analysis and fluid-structure interaction 
analysis on the basis of investigating the rain capacity and water outflow in water-inrush incidents. The quantitative inversion method presented in this paper can be effectively applied in a similar karst area.

\section{Data Availability}

The data used to support the findings of this study are available from the corresponding author upon request.

\section{Conflicts of Interest}

The authors declare that there are no conflicts of interest regarding the publication of this study.

\section{Acknowledgments}

The authors acknowledge the financial support from the National Natural Science Foundation of China (NSFC) (nos. 41372295, U1703244, and 41102178), the Youth Teacher Overseas Research Project, Jiangsu Province, China, and the Postgraduate Research and Practice Innovation Programme of Jiangsu Province (no. KYCX17-0928).

\section{References}

[1] X. Wang, J. Xu, W. Zhu, and Y. Li, "Roof pre-blasting to prevent support crushing and water inrush accidents," International Journal of Mining Science and Technology, vol. 22, no. 3, pp. 379-384, 2012.

[2] J. Wu, S. C. Li, Z. H. Xu et al., "Flow characteristics and escaperoute optimization after water inrush in a backward-excavated karst tunnel," International Journal of Geomechanics, vol. 17, no. 4, Article ID 04016096, 2017.

[3] Y. Kang, Q. Liu, H. Xi, and G. Gong, "Improved compound support system for coal mine tunnels in densely faulted zones: a case study of China's Huainan coal field," Engineering Geology, vol. 240, pp. 10-20, 2018.

[4] G.-H. Zhang, Y.-Y. Jiao, C.-X. Ma, H. Wang, L.-B. Chen, and Z.-C. Tang, "Alteration characteristics of granite contact zone and treatment measures for inrush hazards during tunnel construction-a case study," Engineering Geology, vol. 235, pp. 64-80, 2018.

[5] J. Wu, S. C. Li, and Z. H. Xu, "Numerical analysis of gas-liquid two-phase flow after water inrush from the working face during tunnel excavation in a karst region," Bulletin of Engineering Geology and the Environment, vol. 78, no. 4, pp. 2973-3010, 2019.

[6] A. Andrén and L. Dahlström, Frost Shattering and Ice Problems in Rock Tunnels from a Maintenance Perspective, Stockholm, Sweden, May 2012.

[7] A. Haack, J. Schreyer, and G. Jackel, "Report to ITA working group on maintenance and repair of underground structures: state-of-the-art of non-destructive testing methods for determining the state of a tunnel lining," Tunnelling and Underground Space Technology, vol. 10, no. 413-426, pp. 429-431, 1995.

[8] P. Arjnoi, J.-H. Jeong, C.-Y. Kim, and K.-H. Park, "Effect of drainage conditions on porewater pressure distributions and lining stresses in drained tunnels," Tunnelling and Underground Space Technology, vol. 24, no. 4, pp. 376-389, 2009.

[9] X. Wang, Z. Tan, M. Wang, M. Zhang, and H. Ming, "Theoretical and experimental study of external water pressure on tunnel lining in controlled drainage under high water level,"
Tunnelling and Underground Space Technology, vol. 23, no. 5, pp. 552-560, 2008.

[10] A. Fahimifar and M. R. Zareifard, "A theoretical solution for analysis of tunnels below groundwater considering the hydraulic-mechanical coupling," Tunnelling and Underground Space Technology, vol. 24, no. 6, pp. 634-646, 2009.

[11] D. Kolymbas and P. Wagner, "Groundwater ingress to tunnels-the exact analytical solution," Tunnelling and Underground Space Technology, vol. 22, no. 1, pp. 23-27, 2007.

[12] X. Wang, M. Wang, and M. Zhang, "Simple method to calculate tunnel discharge and external water pressure on lining," Journal of Northern Jiaotong University, vol. 28, 2004.

[13] L. F. Fan, Z. J. Wu, Z. Wan, and J. W. Gao, "Experimental investigation of thermal effects on dynamic behavior of granite," Applied Thermal Engineering, vol. 125, pp. 94-103, 2017.

[14] Q. Fang, H. Song, and D. Zhang, "Complex variable analysis for stress distribution of an underwater tunnel in an elastic half plane," International Journal for Numerical and Analytical Methods in Geomechanics, vol. 39, no. 16, pp. 1821-1835, 2015.

[15] H. Farhadian and H. Katibeh, "New empirical model to evaluate groundwater flow into circular tunnel using multiple regression analysis," International Journal of Mining Science and Technology, vol. 27, no. 3, pp. 415-421, 2017.

[16] G. W. Ma, H. D. Wang, L. F. Fan, and B. Wang, "Simulation of two-phase flow in horizontal fracture networks with numerical manifold method," Advances in Water Resources, vol. 108, pp. 293-309, 2017.

[17] Y. Yuan, X. Jiang, and C. F. Lee, "Tunnel waterproofing practices in China," Tunnelling and Underground Space Technology, vol. 15, no. 2, pp. 227-233, 2000.

[18] Y.-S. Jang, B. Kim, and J.-W. Lee, "Evaluation of discharge capacity of geosynthetic drains for potential use in tunnels," Geotextiles and Geomembranes, vol. 43, no. 3, pp. 228-239, 2015.

[19] C. Yoo, "Hydraulic deterioration of geosynthetic filter drainage system in tunnels-its impact on structural performance of tunnel linings," Geosynthetics International, vol. 23, no. 6, pp. 463-480, 2016.

[20] D. Ma, H. Duan, X. Li, Z. Li, Z. Zhou, and T. Li, "Effects of seepage-induced erosion on nonlinear hydraulic properties of broken red sandstones," Tunnelling and Underground Space Technology, vol. 91, Article ID 102993, 2019.

[21] D. Ma, H. Duan, W. Liu, X. Ma, and M. Tao, "Water-sediment two-phase flow inrush hazard in rock fractures of overburden strata during coal mining," Mine Water and the Environment, vol. 39, no. 2, pp. 308-319, 2020.

[22] S. Li, C. Liu, Z. Zhou, L. Li, S. Shi, and Y. Yuan, "Multi-sources information fusion analysis of water inrush disaster in tunnels based on improved theory of evidence," Tunnelling and Underground Space Technology, vol. 113, Article ID 103948, 2021.

[23] Y. Xue, F. Kong, S. Li et al., "Water and mud inrush hazard in underground engineering: genesis, evolution and prevention," Tunnelling and Underground Space Technology, vol. 114, Article ID 103987, 2021.

[24] J. Wang, S. Li, L. Li, S. Shi, Z. Zhou, and S. Song, "Mechanism of water inrush in fractures and block collapse under hydraulic pressure," Mathematics and Computers in Simulation, vol. 177, pp. 625-642, 2020.

[25] C. Lin, M. Zhang, Z. Zhou et al., "A new quantitative method for risk assessment of water inrush in karst tunnels based on variable weight function and improved cloud model," 
Tunnelling and Underground Space Technology, vol. 95, Article ID 103136, 2020.

[26] S. Wang, L. Li, S. Cheng et al., "Study on an improved realtime monitoring and fusion prewarning method for water inrush in tunnels," Tunnelling and Underground Space Technology, vol. 112, Article ID 103884, 2021. 